\title{
6. OLIGOCENE TO MIDDLE MIOCENE Sr-ISOTOPIC STRATIGRAPHY OF THE NEW JERSEY CONTINENTAL SLOPE ${ }^{1}$
}

\author{
Kenneth G. Miller,,$^{2,3}$ Chengjie Liu, ${ }^{2}$ and Mark D. Feigenson ${ }^{2}$
}

\begin{abstract}
We analyzed specimens of mixed planktonic foraminifer species for Sr isotopes from the Oligocene to middle Miocene sections from boreholes (Ocean Drilling Program Sites 902, 903, 904, and 906; ASP-14, -15) and outcrops on the New Jersey continental slope. We concentrated on the upper Oligocene-middle Miocene at Sites 903 and 904 (444 and $1129 \mathrm{~m}$ present water depth, respectively), the upper Oligocene-lowermost Miocene at Site 902 (811 m water depth), and slope outcrops in Carteret and Lindenkohl canyons. Sr-isotopic age estimates of the Ocean Drilling Program boreholes provide a good stratigraphic framework for upper Oligocene to middle Miocene sections, overcoming problems with rare calcareous plankton zonal markers. When integrated with ongoing biostratigraphic and magnetostratigraphic studies, the Leg 150 sites will provide a precise chronology of slope reflectors that also correlate with sequences boundaries traced under the continental shelf. Preliminary integration is encouraging: (1) nine of the 10 Oligocene to middle Miocene slope reflectors (sequence boundaries) correlate with global $\delta^{18} \mathrm{O}$ increases and with sequence boundaries in the onshore New Jersey coastal plain, arguing for a causal link between formation of sequence boundaries and glacioeustatic lowerings; and (2) several hiatuses on the slope also correlate with reflectors and the major $\delta^{18} \mathrm{O}$ increases, although many of the seismic reflectors appear to be conformable at the slope boreholes. Outcrop studies date a major change in depositional regime in the earliest Oligocene; this "siliciclastic switch" from an Eocene carbonate ramp to a starved siliciclastic early Oligocene margin correlates with a global $\delta^{18} \mathrm{O}$ increase and a regional cooling. Sediment starvation in the early Oligocene resulted in a poorly preserved record on the slope. Sedimentation rates subsequently increased in the middle Oligocene on the entire margin, when prograding clinoforms appeared beneath the modern shelf and rates increased again in the early to middle Miocene. We attribute this progradational change to lower long-term sea level, although hinterland tectonics may have played an important role.
\end{abstract}

\section{INTRODUCTION}

Two primary goals of Ocean Drilling Program (ODP) Leg 150 were to date major Oligocene to Holocene unconformities on the New Jersey Margin and to evaluate their correlation with glacioeustatic age estimates obtained from global $\delta^{18} \mathrm{O}$ changes (see Miller and Mountain, 1994, for discussion). The lower to middle Miocene on this margin is particularly interesting because the excellent seismic sequence geometries beneath the New Jersey shelf (Greenlee et al., 1988; 1992; Greenlee and Moore, 1988) can be compared with the inferred record of glacioeustatic change (Miller et al., 1991c; Wright and Miller, 1992). Multichannel and single-channel seismic grids collected with the Maurice Ewing allow the tracing of seismic sequences from the shelf to the slope (Miller and Mountain, 1994). Leg 150 drilled at four sites on the New Jersey continental slope to date these seismic reflectors. Because these sites were drilled in deep water ( $>400 \mathrm{~m}$ present depth), we hoped that they would recover (hemi-) pelagic sections that were not only more continuous than shelf sections (i.e., the correlative conformities of Vail et al., 1977), but also contained planktonic microfossils suitable for biostratigraphic correlations.

The first goal in addressing sea-level history is to date sequences with excellent age control (with resolution better than 0.5 m.y.; SeaLevel Working Group, 1992). Sr-isotopic studies allow age estimates ("dates") to be obtained from in situ, unaltered marine carbonates, even those with poor biostratigraphic control. Sr-isotopic studies have proven to be particularly useful in dating sequences on the New

Mountain, G.S., Miller, K.G., Blum, P., Poag, C.W., and Twichell, D.C. (Eds.), 1996. Proc. ODP, Sci. Results, 150: College Station, TX (Ocean Drilling Program).

${ }^{2}$ Department of Geological Sciences, Rutgers University, Piscataway, NJ 08855 , U.S.A. Miller: kgm@rci.rutgers.edu U.S.A.
Jersey Margin. For example, the chronology of Miocene onshore sequences largely relies on $\mathrm{Sr}$ isotopes (Sugarman et al., 1993; Miller et al., 1994a, 1994b; Cape May site report [Miller et al., 150X (Suppl.), this volume]; Miller and Sugarman, 1995). This study shows that $\mathrm{Sr}$ isotopes are also extremely useful in evaluating the chronology of Oligocene to Miocene New Jersey slope sequences. Although $\mathrm{Sr}$-isotopic studies provide a good chronology of slope sequences, age resolution using $\mathrm{Sr}$ stratigraphy alone $( \pm 0.6$ to $1.0 \mathrm{~m} . \mathrm{y}$. for the Oligocene, \pm 0.3 to $0.6 \mathrm{~m}$.y. for the early Miocene, \pm 0.9 to 1.4 m.y. for the middle Miocene; Miller et al., 1991b; Oslick et al., 1994; see "Methods") is usually insufficient to date sequences. Requisite age control can be obtained only by integrating biostratigraphy, isotopic ( $\mathrm{Sr}$, oxygen, and carbon) stratigraphy, and magnetostratigraphy.

Before drilling the slope, we evaluated the limited Oligocene to Miocene sections recovered at slope Site 612 (1400 m present depth) (Poag, Watts, et al., 1987; Miller and Hart, 1987; Miller et al., 1991a; Fig. 1A), sampled slope outcrops using the Alvin in 1989 (Fig. 1B), and examined samples from two discontinuously sampled slope boreholes (Atlantic Slope Project [ASP]-14, $1191 \mathrm{~m}$ water depth, and ASP-15, $1493 \mathrm{~m}$ water depth; Melillo, 1985). These preliminary studies (reported here) show that sufficient carbonate and planktonic foraminifers are found in Oligocene to Miocene strata to date the slope sections. The slope outcrop samples yield the best age estimates of the regional change in depositional regime from carbonate to siliciclastic sedimentation.

Four slope sites were drilled during Leg 150, targeting upper Oligocene to Miocene strata. We applied $\mathrm{Sr}$-isotopic stratigraphy to material obtained from the New Jersey continental slope to improve age resolution and resolve stratigraphic ambiguities:

1. At Site 902 ( $811 \mathrm{~m}$ water depth; Fig. 1A), most of the lower to middle Miocene section was devoid of primary carbonate; diatoms (Burckle, this volume) and dinocysts (de Verteuil, this volume) pro- 
Figure 1. A. SeaBeam bathymetric location map of the middle continental slope (500-1500 m water depth) drilled during Leg 150 showing Sites 612, 902-904, 906, AMCOR 6021 (Hathaway et al., 1976), and Carteret Canyon outcrop (after Mountain, Miller, Blum, et al., 1994). B. SeaBeam bathymetric location map of the middle-lower continental slope ( $>500 \mathrm{~m}$ water depth) and upper continental rise between Lindenkohl and Carteret canyons showing Lindenkohl Canyon, amphitheater, Lower Berkeley Canyon, and Carteret Canyon outcrops, Sites 612 and 904, ASP-14 and -15, piston (closed PC16 (Lindenkohl Canyon) is the only piston or gravity core to sample Oligocene-Miocene strata. SeaBeam data were collected by Atlantis II 120 and Insets show close-ups of Hydrosweep bathymetric data collected by Maurice Ewing cruise 9009 of the Carteret Canyon and Lindenkohl Canyon outcrops (Dives 2169 and 2174, respectively). Arrows indicate the thalwegs of the canyons that breach the shelf break. circles) and gravity cores (open circles) obtained on Atlantic II 120 and 124. 124 and processed by D. Twichell and W.B.F. Ryan (unpubl. data, 1989).

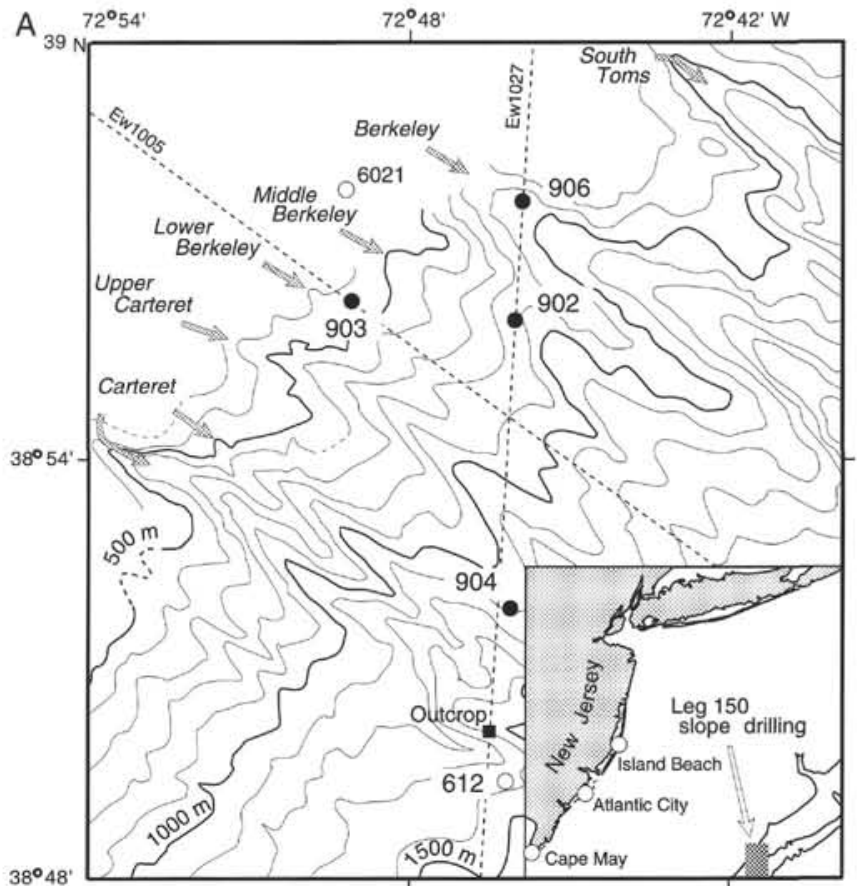

B

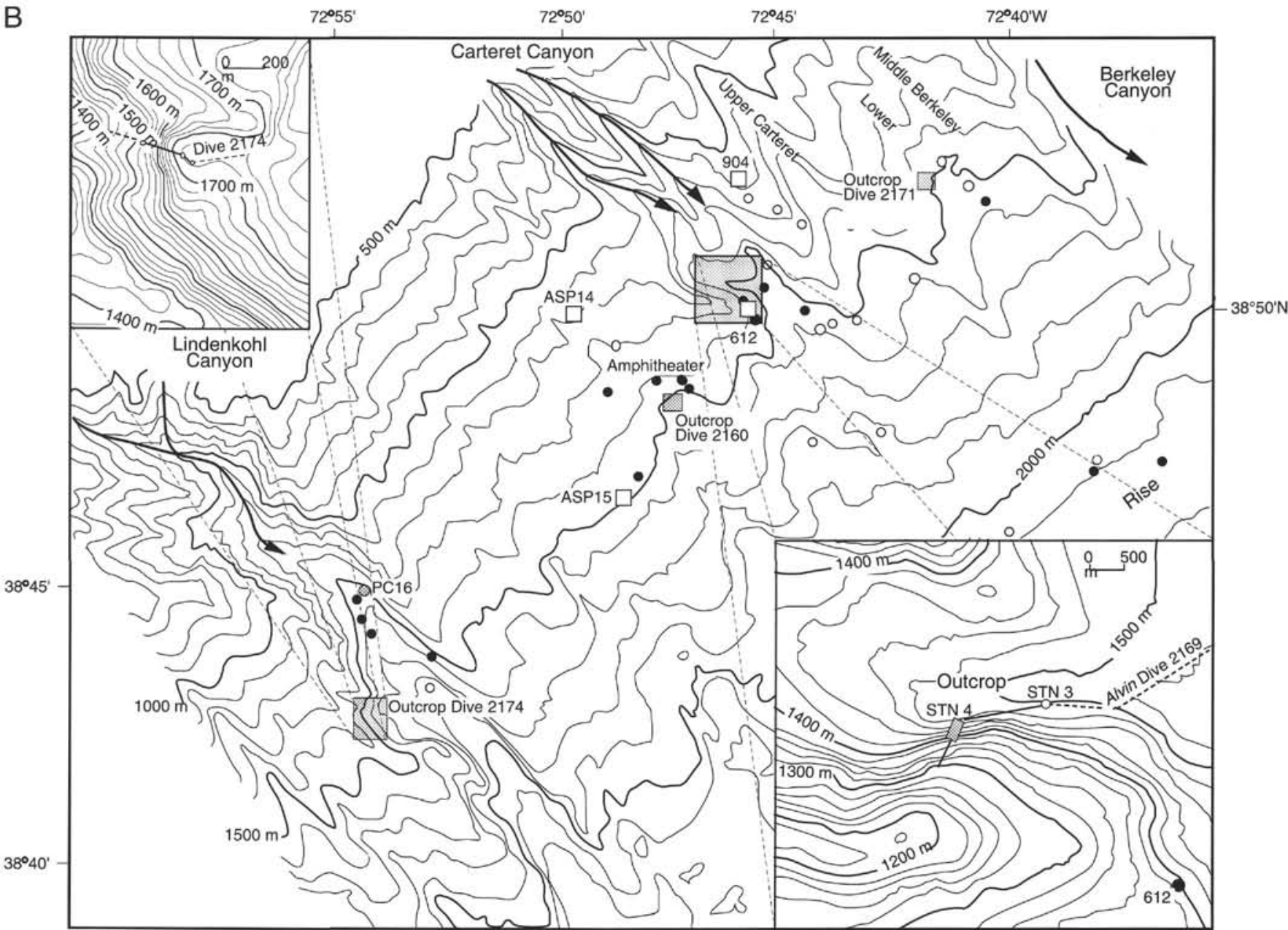




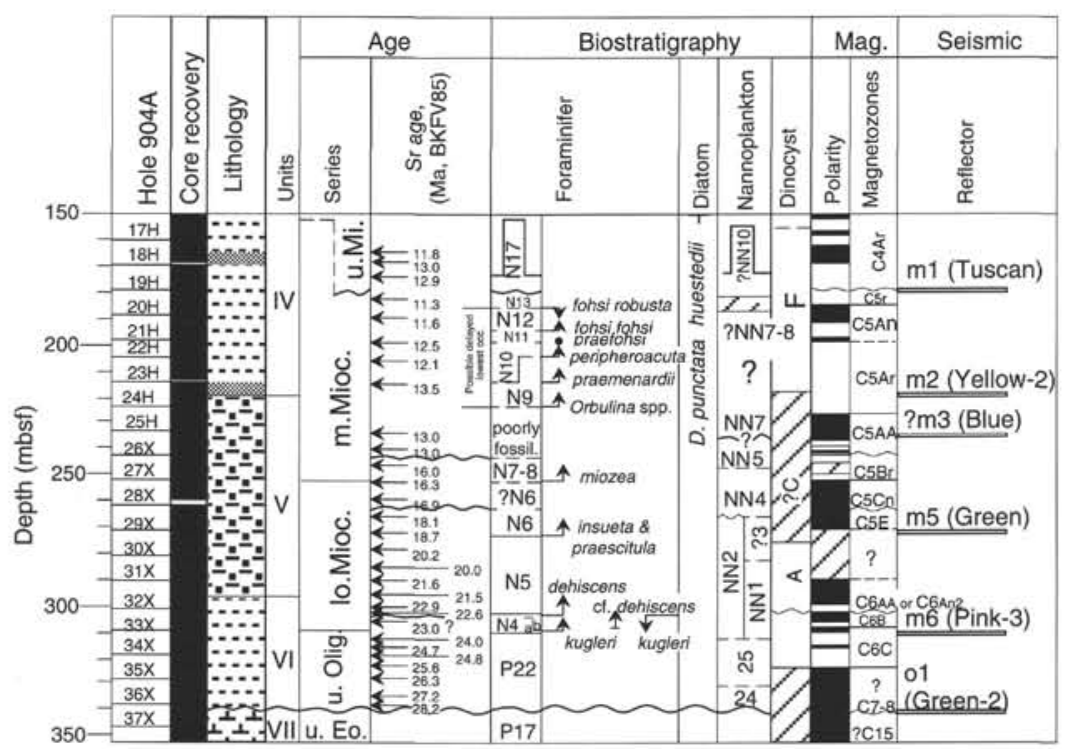

Figure 2. Integrated uppermost Eocene to lower upper Miocene section, Site 904, showing recovery (black is recovered, white is nonrecovered), lithostratigraphic units (Mountain, Miller, Blum, et al., 1994), Sr-isotopic age estimates using the Berggren et al. (1985) (BKFV85) time scale (see Table 1), planktonic foraminifer biostratigraphy (Snyder et al., this volume), diatoms (Burckle in Mountain, Miller, Blum, et al., 1994), nannofossil biostratigraphy (left column, Aubry in Mountain, Miller, Blum, et al., 1994; right column, Gartner in Mountain, Miller, Blum, et al., 1994), dinocysts (de Verteuil, in Mountain, Miller, Blum, et al., 1994), magnetostratigraphy (Van Fossen and Urbat, this volume), and seismic reflectors (Mountain, Miller, Blum, et al., 1994). Arrows are placed on samples; zonal boundaries are placed between samples.

vide the primary means of dating the Miocene section. Although these groups provide good zonations, they are poorly calibrated to the Geomagnetic Polarity Time Scale (GPTS). Sr isotopes provide a means of correlating the upper Oligocene to lowermost Miocene to the GPTS at this site.

2. The Miocene section at Site 903 (444 m water depth; Fig. 1A) contains planktonic foraminifers and nannofossils (Mountain, Miller, Blum, et al., 1994). However, they are rare due to dilution and diagenetic dissolution. As a result, shipboard age control for the Miocene section at Site 903 depended primarily on diatoms and dinocysts. Large (up to $30 \mathrm{~cm}^{3}$ ) samples from the upper Oligocene to middle Miocene at Site 903 provided sufficient carbonate for dating the thick middle (nearly $400 \mathrm{~m}$ ) and lower $(\sim 100 \mathrm{~m})$ Miocene sections with $\mathrm{Sr}$ isotopes.

3. Site 904 (1129 m water depth) was successful in obtaining a lower Miocene section with sufficient carbonate fossils for biostratigraphic correlation and Sr-isotopic studies (Mountain, Miller, Blum, et al., 1994) and a good magnetostratigraphic record (Van Fossen and Urbat, this volume) (Fig. 2). However, shipboard biostratigraphic studies were contradictory and somewhat ambiguous for the middle Miocene section. Integration of Sr-isotopic, biostratigraphic, and magnetostratigraphic studies at this site provides the best chronology of Oligocene to Miocene slope sections obtained on the New Jersey slope.

4. Site 906 (913 $\mathrm{m}$ water depth) was drilled in the thalweg of modern Berkeley Canyon (Fig. 1A) and was designed to sample and date a buried Miocene canyon formed at or near the level of Reflector $\mathrm{m} 3$ (middle middle Miocene). The difficult-to-date canyon fill was dated with $\mathrm{Sr}$ isotopes.

Integration of Sr-isotopic data (Table 1) from these four sites with magnetostratigraphic and biostratigraphic studies (Figs. 2-6) provided excellent age control on upper Oligocene through middle Miocene sequences (Figs. 2-6), allowing us to attain two of the primary goals of Leg 150: dating sequences and evaluating their correlation to the $\delta^{18} \mathrm{O}$ record. We compare the ages of sequences on the New Jersey slope with the sequences on the onshore coastal plain and with the $\delta^{18} \mathrm{O}$ proxy of glacioeustasy and find good agreement among the three.

\section{METHODS}

\section{Surveys}

Detailed single- and multichannel seismic grids were collected on the shelf and slope by Ewing 9009 (Miller and Mountain, 1994) and on the slope by Leg 150 (Mountain, Miller, Blum, et al., 1994). These seismic grids were tied into outcrops and available boreholes, providing the means for tying shelf sequences into slope stratigraphy.

Slope outcrops were sampled in 1989 using the submersible Alvin. We used previously published bathymetric maps (Farre and Ryan, 1987) and drilling results from Deep Sea Drilling Project (DSDP) Leg 95 (Poag, Watts, et al., 1987; Miller et al., 1987b) to determine potential outcrop areas. SeaBeam bathymetric data were collected by Atlantis II 120 and 124, and bathymetric maps were produced by D. Twichell and W.B.F. Ryan; these maps provided a detailed guide to outcrop locations (Fig. 1). In addition, the SeaBeam bathymetry was used during Leg 150 to locate sites on the steeply sloping topography (Fig. 1A; Mountain, Miller, Blum, et al., 1994). Outcrops were remapped using Hydrosweep bathymetry on Ewing 9009 (Fig. 1B, insets), yielding better resolution of the nearly vertical outcrop walls (e.g., Dive 2169, Station 4, Fig. 1B). The western walls of canyons appeared sharper in remote sensing data (SeaMARK, Farre and Ryan, 1987; SeaBeam, Fig. 1; and Hydrosweep, Fig. 1B, inset), and we targeted these as the best outcrop locations.

\section{Sampling}

Eocene to Pliocene outcrops were sampled on Dives 2160 (slope amphitheater; Fig. 1B), 2169 (Carteret Canyon; Figs. 1A, B; note dive track on inset, Fig. 1B), 2171 (Lower Berkeley Canyon; Fig. 1), and 2174 (Lindenkohl Canyon; note dive track on inset, Fig. 1B). 
Table 1. Sr-isotopic data for foraminifers at Leg 150 sites.

\begin{tabular}{|c|c|c|c|c|c|c|}
\hline \multirow[b]{2}{*}{$\begin{array}{l}\text { Core, section, } \\
\text { interval }(\mathrm{cm})\end{array}$} & \multirow[b]{2}{*}{$\begin{array}{l}\text { Depth } \\
\text { (mbsf) }\end{array}$} & \multirow[b]{2}{*}{$\begin{array}{c}{ }^{87} \mathrm{Sr} /{ }^{86} \mathrm{Sr} \\
\text { ratio }\end{array}$} & \multirow[b]{2}{*}{$\begin{array}{l}\text { Error }^{\mathrm{a}} \\
( \pm)\end{array}$} & \multicolumn{2}{|c|}{ Sr age } & \multirow{2}{*}{$\begin{array}{l}\text { Age error } \\
\text { (Ma) } \\
\text { error } / \text { error }\end{array}$} \\
\hline & & & & $\begin{array}{c}(\mathrm{Ma}) \\
(\mathrm{BKFV} 85)\end{array}$ & $\begin{array}{l}\text { (Ma) } \\
\text { (CK92) }\end{array}$ & \\
\hline \multicolumn{7}{|l|}{ 150-902D- } \\
\hline $65 X-2,32-35$ & 595.52 & 0.708330 & 0.000009 & 22.04 & 22.78 & $0.29 / 0.6$ \\
\hline $66 X-1,47-50$ & 603.77 & 0.708298 & 0.000008 & 22.96 & 23.41 & $0.29 / 0.6$ \\
\hline $66 \times-5,50-52$ & 609.80 & 0.708291 & 0.000008 & 23.16 & 23.54 & $0.58 / 1.0$ \\
\hline $67 \times-3,46-49$ & 616.46 & 0.708171 & 0.000010 & 26.61 & 25.88 & $0.58 / 1.0$ \\
\hline $68 \mathrm{X}-3,50-53$ & 625.70 & 0.708175 & 0.000007 & 26.50 & 25.80 & $0.58 / 1.0$ \\
\hline $68 X-5,53-55$ & 628.73 & 0.708155 & 0.000009 & 27.07 & 26.19 & $0.58 / 1.0$ \\
\hline $69 X-3,51-54$ & 635.41 & 0.708125 & 0.000005 & 27.94 & 26.77 & $0.58 / 1.0$ \\
\hline $70 X-1,53-55$ & 642.13 & 0.708144 & 0.000014 & 27.39 & 26.40 & $0.58 / 1.0$ \\
\hline $70 X-3,54-56$ & 645.14 & 0.708111 & 0.000013 & 28.34 & 27.04 & $0.58 / 1.0$ \\
\hline $71 X-1,47-49$ & 651.67 & 0.708115 & 0.000008 & 28.22 & 26.97 & $0.58 / 1.0$ \\
\hline $71 X-5,51-54$ & 657.71 & 0.708093 & 0.000008 & 28.86 & 27.39 & $0.58 / 1.0$ \\
\hline $72 X-3,50-53$ & 664.40 & 0.708046 & 0.000010 & 30.21 & 28.31 & $0.58 / 1.0$ \\
\hline $73 X-1,48-51$ & 670.98 & 0.708064 & 0.000010 & 29.69 & 27.96 & $0.58 / 1.0$ \\
\hline $73 X-5,53-56$ & 677.03 & 0.708053 & 0.000011 & 30.01 & 28.17 & $0.58 / 1.0$ \\
\hline $73 X-5,53-56$ & 677.03 & 0.708024 & 0.000023 & 30.84 & 28.74 & $0.58 / 1.0$ \\
\hline $\begin{array}{l}150-903 \mathrm{~A}- \\
73 \mathrm{H}-1,108-113\end{array}$ & 665.18 & 0.708812 & 0.000027 & 14.49 & 14.37 & $0.90 / 1.4$ \\
\hline $150-903 \mathrm{C}$ - & & & & & & \\
\hline 23R-3, 110-113 & 799.00 & 0.708834 & 0.000007 & 13.50 & 13.54 & $0.90 / 1.4$ \\
\hline $39 \mathrm{R}-1,110-112$ & 949.70 & 0.708619 & 0.000006 & 18.37 & 18.09 & $0.29 / 0.6$ \\
\hline $4 \mid R-3,111-114$ & 971.11 & 0.708467 & 0.000014 & 20.57 & 20.32 & $0.29 / 0.6$ \\
\hline $45 \mathrm{R}-1,110-113$ & 1007.30 & 0.708129 & 0.000008 & 27.82 & 26.69 & $0.29 / 0.6$ \\
\hline 150-903D- & & & & & & \\
\hline $4 R-1,50-53$ & 804.30 & 0.708857 & 0.000008 & 12.47 & 12.67 & $0.90 / 1.4$ \\
\hline $4 \mathrm{R}-3,50-53$ & 807.30 & 0.708857 & 0.000005 & 12,47 & 12.67 & $0.90 / 1.4$ \\
\hline $6 R-5,52-55$ & 829.62 & 0.708855 & 0.000005 & 12.56 & 12.75 & $0.90 / 1.4$ \\
\hline $7 R-3,61-63$ & 836.41 & 0.708835 & 0.000011 & 13.46 & 13.50 & $0.90 / 1.4$ \\
\hline $9 \mathrm{R}-1,49-51$ & 852.49 & 0.708785 & 0.000015 & 15.70 & 15.38 & $0.29 / 0.6$ \\
\hline $11 \mathrm{R}-3,48-51$ & 874.78 & 0.708795 & 0.000007 & 15.25 & 15.00 & $0.29 / 0.6$ \\
\hline $13 R-3,49-52$ & 894.19 & 0.708810 & 0.000006 & 14.58 & 14.44 & $0.29 / 0.6$ \\
\hline $14 \mathrm{R}-1,55-57$ & 900.75 & 0.708744 & 0.000021 & 16.56 & 16.26 & $0.29 / 0.6$ \\
\hline $14 \mathrm{R}-3,51-54$ & 903.71 & 0.708761 & 0.000008 & 16.32 & 16.01 & $0.29 / 0.6$ \\
\hline $15 R-1,50-53$ & 910.20 & 0.708633 & 0.000007 & 18.17 & 17.89 & $0.29 / 0.6$ \\
\hline $16 \mathrm{R}-1,55-58$ & 919.75 & 0.708640 & 0.000021 & 18.07 & 17.79 & $0.29 / 0.6$ \\
\hline $17 \mathrm{R}-1,56-58$ & 929.36 & 0.708629 & 0.000010 & 18.22 & 17.95 & $0.29 / 0.6$ \\
\hline $18 R-3,65-68$ & 942.05 & 0.708625 & 0.000011 & 18.28 & 18.01 & $0.29 / 0.6$ \\
\hline $19 \mathrm{R}-3,55-58$ & 979.55 & 0.708353 & 0.000008 & 22.21 & 21.99 & $0.29 / 0.6$ \\
\hline 19R-CC & 986.60 & 0.708392 & 0.000008 & 21.65 & 21.42 & $0.29 / 0.6$ \\
\hline $20 \mathrm{R}-4,53-55$ & 990.53 & 0.708361 & 0.000006 & 22.10 & 21.87 & $0.29 / 0.6$ \\
\hline $21 R-4,55-57$ & 1000.01 & 0.708360 & 0.000009 & 22.17 & 21.94 & $0.29 / 0.6$ \\
\hline $21 R-6,51-53$ & 1003.01 & 0.708261 & 0.000008 & 24.03 & 24.13 & $0.58 / 1.0$ \\
\hline $24 \mathrm{R}-2,137-139$ & 1028.17 & 0.708116 & 0.000006 & 28.20 & 26.95 & $0.58 / 1.0$ \\
\hline $25 \mathrm{R}-1,56-58$ & 1029.56 & 0.708066 & 0.000007 & 29.63 & 27.92 & $0.58 / 1.0$ \\
\hline $25 \mathrm{R}-3,56-58$ & 1032.56 & 0.708102 & 0.000014 & 28.60 & 27.22 & $0.58 / 1.0$ \\
\hline $25 \mathrm{R}-5,54-56$ & 1035.54 & 0.708067 & 0.000009 & 29.60 & 27.90 & $0.58 / 1.0$ \\
\hline $25 R-5,54-56$ & 1035.54 & $0.708242^{d}$ & 0.000054 & 24.57 & 24.49 & $0.58 / 1.0$ \\
\hline $150-904 \mathrm{~A}-$ & & & & & & \\
\hline $18 \mathrm{H}-3,108-113$ & 162.58 & 0.708872 & 0.000009 & 11.80 & 12.11 & $0.90 / 1.4$ \\
\hline $18 \mathrm{H}-\mathrm{CC}$ & 167.7 & 0.708846 & 0.000011 & 12.96 & 13.09 & $0.90 / 1.4$ \\
\hline $19 \mathrm{H}-3,110-115$ & 172.10 & 0.708847 & 0.000008 & 12.92 & 13.05 & $0.90 / 1.4$ \\
\hline $20 \mathrm{H}-3,110-112$ & 181.60 & 0.708883 & 0.000008 & 11.30 & 11.70 & $0.90 / 1.4$ \\
\hline $21 \mathrm{H}-1,110-112$ & 188.10 & 0.708877 & 0.000012 & 11.57 & 11.92 & $0.90 / 1.4$ \\
\hline $22 \mathrm{H}-1,110-114$ & 197.60 & 0.708856 & 0.000008 & 12.51 & 12.71 & $0.90 / 1.4$ \\
\hline $23 \mathrm{H}-1,110-114$ & 204.10 & 0.708865 & 0.000007 & 12.11 & 12.37 & $0.90 / 1.4$ \\
\hline $24 \mathrm{H}-1,110-115$ & 213.60 & 0.708835 & 0.000008 & 13.46 & 13.50 & $0.90 / 1.4$ \\
\hline $26 \mathrm{X}-1,110-115$ & 232.40 & 0.708846 & 0.000011 & 12.96 & 13.09 & $0.90 / 1.4$ \\
\hline $26 \mathrm{X}-5,110-115$ & 238.40 & 0.708846 & 0.000006 & 12.96 & 13.09 & $0.90 / 1.4$ \\
\hline $27 \mathrm{X}-3,110-115$ & 245.00 & 0.708786 & 0.000012 & 15.96 & 15.65 & $0.29 / 0.6$ \\
\hline $28 \mathrm{X}-1,110-115$ & 251.40 & 0.708763 & 0.000007 & 16.29 & 15.99 & $0.29 / 0.6$ \\
\hline $28 \mathrm{X}-6,9-14$ & 257.39 & 0.708724 & 0.000009 & 16.85 & 16.56 & $0.29 / 0.6$ \\
\hline $29 \mathrm{X}-3,110-114$ & 264.20 & 0.708636 & 0.000012 & 18.12 & 17.84 & $0.29 / 0.6$ \\
\hline $30 \mathrm{X}-1,110-114$ & 270.90 & 0.708593 & 0.000009 & 18.74 & 18.47 & $0.29 / 0.6$ \\
\hline $30 \times-5,110-114$ & 276.90 & 0.708494 & 0.000011 & 20.18 & 19.92 & $0.29 / 0.6$ \\
\hline $31 X-3,110-112$ & 283.60 & 0.708506 & 0.000006 & 20.00 & 19.75 & $0.29 / 0.6$ \\
\hline $31 X-6,110-115$ & 288.10 & 0.708399 & 0.000007 & 21.55 & 21.31 & $0.29 / 0.6$ \\
\hline $32 X-3,110-115$ & 293.20 & 0.708404 & 0.000006 & 21.48 & 21.24 & $0.29 / 0.6$ \\
\hline $32 X-6,110-115$ & 297.70 & 0.708307 & 0.000009 & 22.88 & 22.66 & $0.58 / 1.0$ \\
\hline $33 \mathrm{X}-1,110-115$ & 299.90 & 0.708329 & 0.000010 & 22.56 & 22.34 & $0.58 / 1.0$ \\
\hline $33 X-3,110-115$ & 302.90 & 0.708296 & 0.000023 & 23.02 & 23.44 & $0.58 / 1.0$ \\
\hline $34 \mathrm{X}-1,110-115$ & 309.50 & 0.708260 & 0.000016 & 24.05 & 24.14 & $0.58 / 1.0$ \\
\hline $34 X-3,110-115$ & 312.50 & 0.708239 & 0.000011 & 24.66 & 24.55 & $0.58 / 1.0$ \\
\hline $34 X-5,110-115$ & 315.50 & 0.708234 & 0.000011 & 24.80 & 24.65 & $0.58 / 1.0$ \\
\hline $35 X-1,108-113$ & 318.88 & 0.708207 & 0.000005 & 25.58 & 25.18 & $0.58 / 1.0$ \\
\hline $35 X-5,108-113$ & 324.88 & 0.708183 & 0.000009 & 26.27 & 25.64 & $0.58 / 1.0$ \\
\hline $36 X-3,108-113$ & 331.28 & 0.708151 & 0.000006 & 27.19 & 26.27 & $0.58 / 1.0$ \\
\hline $36 X-5,108-113$ & 334.28 & 0.708117 & 0.000015 & 28.17 & 26.93 & $0.58 / 1.0$ \\
\hline
\end{tabular}


Table 1 (continued).

\begin{tabular}{|c|c|c|c|c|c|c|}
\hline \multirow[b]{2}{*}{$\begin{array}{l}\text { Core, section, } \\
\text { interval }(\mathrm{cm})\end{array}$} & \multirow[b]{2}{*}{$\begin{array}{l}\text { Depth } \\
\text { (mbsf) }\end{array}$} & \multirow[b]{2}{*}{$\begin{array}{c}{ }^{87} \mathrm{Sr} /{ }^{86} \mathrm{Sr} \\
\text { ratio }\end{array}$} & \multirow[b]{2}{*}{$\begin{array}{l}\text { Error }^{\mathrm{a}} \\
( \pm)\end{array}$} & \multicolumn{2}{|c|}{ Sr age } & \multirow{2}{*}{$\begin{array}{c}\text { Age error } \\
\text { (Ma) } \\
\text { error } / \text { error }\end{array}$} \\
\hline & & & & $\begin{array}{c}\text { (Ma) } \\
\text { (BKFV85) }\end{array}$ & $\begin{array}{c}\text { (Ma) } \\
(\mathrm{CK} 92)\end{array}$ & \\
\hline \multicolumn{7}{|l|}{$150-906 \mathrm{~A}-$} \\
\hline $46 X-5,52-54$ & 435.30 & 0.708829 & 0.000009 & 13.73 & 13.73 & $0.90 / 1.4$ \\
\hline $49 X-5,45-48$ & 467.38 & 0.708853 & 0.000014 & 12.65 & 12.82 & $0.90 / 1.4$ \\
\hline $51 X-5,49-52$ & 483.68 & 0.708159 & 0.000006 & 26.96 & 26.11 & $0.58 / 1.0$ \\
\hline $54 X-2,55-57$ & 508.48 & 0.708107 & 0.000015 & 28.45 & 27.12 & $0.58 / 1.0$ \\
\hline $58 X-5,23-26$ & 550.32 & 0.708041 & 0.000006 & 30.35 & 28.83 & $0.58 / 1.0$ \\
\hline $60 X-1,50-52$ & 564.28 & 0.707830 & 0.000006 & 36.42 & 34.60 & $0.58 / 1.0$ \\
\hline
\end{tabular}

${ }^{a}$ Machine precision.

'Theoretical minimal age error.

${ }^{c}$ Conservative age error estimate for a single analysis at $95 \%$ confidence interval (shown on figures),

${ }^{\mathrm{d}}$ Analysis is considered anomalous and is not plotted.

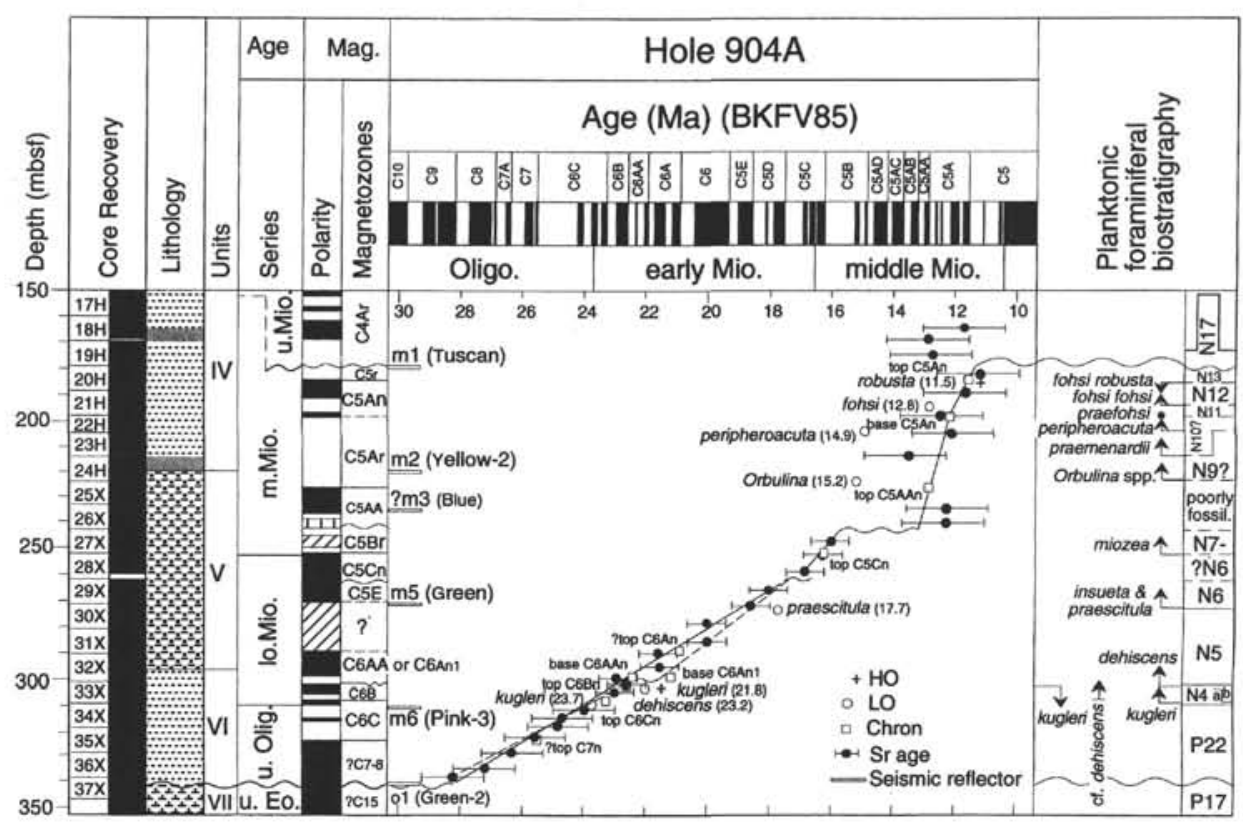

Figure 3. Age-depth diagram, Site 904, showing Sr-isotopic ages (see Table 1), planktonic foraminifer (Snyder et al., this volume) and magnetostratigraphic (Van Fossen and Urbat, this volume) age estimates, and the time scale of BKFV85. HO = highest occurrence, LO = lowest occurrence. Errors for Sr-isotopic ages are $\pm 1 \mathrm{~m} . \mathrm{y}$. for $35-22.8 \mathrm{Ma}, \pm 0.6 \mathrm{~m} . \mathrm{y}$. for $22.8-15.6 \mathrm{Ma}$, and $\pm 1.4 \mathrm{~m} . \mathrm{y}$. for 15.6-9.2 Ma (Oslick et al., 1994). Dashed line indicates alternative age model (see text for discussion)

Samples were obtained with sharpened polycarbonate 2.5 -in-diameter push-cores typically used by the Alvin (A-cores), stainless-steel push-cores provided by Bedford Institute of Oceanography (Bcores), auger-type hand-cores (C-cores), and the Alvin manipulator arm (Figs. 7, 8). A-cores tended not to penetrate the outcrops and often sampled only recent drape sediments. Sections at Carteret and Lindenkohl canyons were the best sampled (Figs. 7, 8), and we focused our outcrop studies on these samples, examining them for planktonic foraminifer (Table 2) and radiolarian (A. Palmer-Julson, pers. comm., 1990; Table 2) biostratigraphic and Sr-isotopic studies (Table 2). Piston and gravity cores penetrated Eocene outcrops at several sites and a Miocene outcrop at one site (AII 120-02 PC16, $1551 \mathrm{~m}$ depth corrected for wire angle; Fig. 1B); however, most of the gravity and piston cores sampled Pleistocene to Holocene strata (Fig. 1B).

The discontinuously cored ASP-14 and ASP-15 sites (Fig. 1A) were examined by Melillo (1985) for planktonic foraminiferal biostratigraphic studies. We analyzed nine of his samples from ASP-14 and -15 for $\mathrm{Sr}$-isotopic studies (Table 2).
Continuous coring at ODP Sites 902,903, 904, and 906 provides the thickest and most complete Oligocene to Miocene sections from the New Jersey slope. We obtained one to three $20-\mathrm{cm}^{3}$ samples per core from Sites 902, 903, and 904. Many of the Site 903 Miocene samples from 891 to $775 \mathrm{~m}$ below seafloor (mbsf) and the Site 902 Miocene samples from 595 to 122 mbsf were barren to nearly barren of foraminiferal and shell carbonate. Therefore, we focused our initial studies on Site 904, obtaining $28 \mathrm{Sr}$-isotopic analyses. We subsequently resampled Site 903 and obtained large volume $\left(30 \mathrm{~cm}^{3}\right)$ samples adjacent to levels that proved to contain foraminifers. Corecatcher samples from the Site 906 Miocene section were barren or contained only rare foraminifers; subsequent benthic foraminifer studies (Katz and Miller, this volume) identified fossiliferous samples that were then analyzed for $\mathrm{Sr}$-isotopic stratigraphy.

\section{Sr-Isotopic Studies}

$\mathrm{Sr}$-isotopic age estimates were obtained from planktonic foraminifers recovered from slope outcrops and boreholes (Tables 1, 2; Figs. 


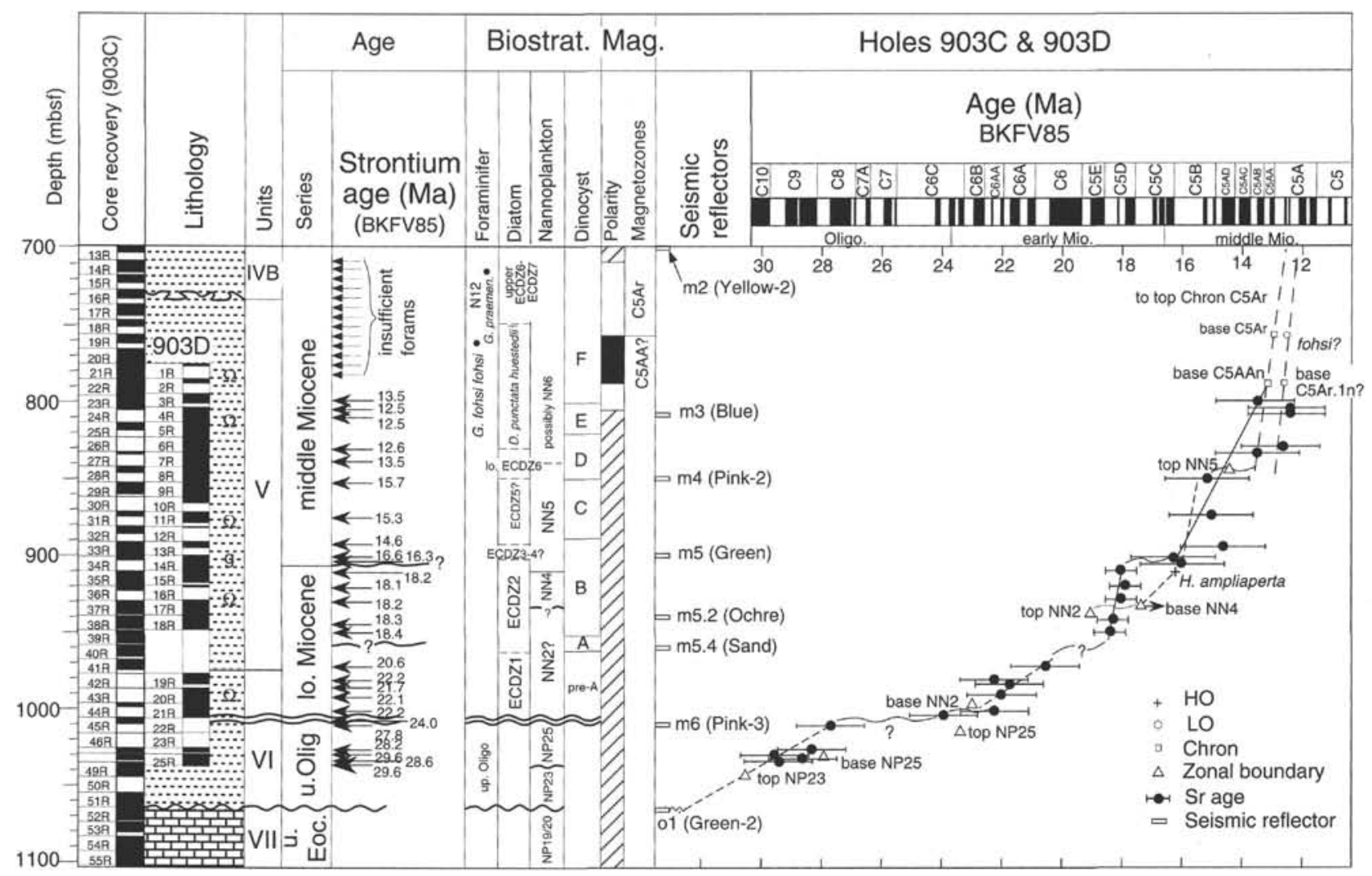

Figure 4. Integrated uppermost Eocene to middle Miocene section and age-depth diagram, Site 903. See Figure 2 caption for explanation. Data for age-depth plot include the LO of Globorotalia fohsi fohsi, 757 mbsf, 12.6 Ma; top Zone NN5, 846.49 mbsf, 14.4 Ma; top Zone NN2, 938 mbsf, 18.9 Ma; base Zone NN2, 988 mbsf, 23.2 Ma; top Zone NP25, 1014 mbsf, 23.7 Ma; base Zone NP25, 1033.8 mbsf, 28 Ma; top Zone NP23, 1045 mbsf, 30.3 Ma; base Zone NP23, 1064.1 mbsf, 36.7 Ma. Dashed line indicates alternative or uncertain age model.

1-8). The samples examined show little evidence of stratigraphic mixing except as noted here (see "Results") and in Katz and Miller (this volume). Approximately 200 specimens per sample of mixed planktonic foraminiferal species were ultrasonically treated in tap water and dissolved in $1.5 \mathrm{~N} \mathrm{HCl}$. Strontium was separated using standard ion exchange techniques and analyzed on a VG sector mass spectrometer at Rutgers University (see Miller et al., 1991b, for procedures). At Rutgers, NBS987 is routinely measured as 0.710255 ${ }^{87} \mathrm{Sr} /{ }^{86} \mathrm{Sr}$ (20 analyses, $1 \sigma= \pm 0.000008$, normalized to ${ }^{86} \mathrm{Sr} /{ }^{88} \mathrm{Sr}=$ 0.1194; Oslick et al., 1994). EN-1 (an informal Sr isotope standard) has been measured as 0.709191 (two analyses; Miller et al., 1991b). Internal precision (intra-run variability) averaged \pm 0.000010 for the analyses presented here $(n=99$; Tables 1,2$)$. We have previously estimated that our external precision (inter-run variability) ranged from \pm 0.000020 to \pm 0.000030 (Miller et al., 1988, 1991b; Oslick et al., 1994). We use \pm 0.000020 in computing theoretical maximum stratigraphic resolution (Table 1) and believe that this is a reasonable estimate of our sample reproducibility based on residuals from linear regressions (Miller et al., 1991b; Oslick et al., 1994) and the discussion below.

Ages were assigned using both the Berggren et al. (1985; BKFV85) and Cande and Kent (1992; CK92) time scales (Tables 1, 2); results are discussed using BKFV85 to compare with previous $\mathrm{Sr}$ isotopic studies of the New Jersey coastal plain (Miller et al., 1994a, 1994b; Cape May site report [Miller et al., 150X (Suppl.), this volume]).

The late Eocene to Oligocene age-Sr regressions are those of Miller et al. (1988) and Oslick et al. (1994), which rely on the BKFV85 and CK92 time scales, respectively. These regressions are based on
Sr-isotopic data from two sites with excellent magnetostratigraphic records: Site 522 (late Eocene to Oligocene; Miller et al., 1988) and Site 747 (latest Oligocene to early late Miocene; Oslick et al., 1994). Miocene age estimates were based on Oslick et al. (1994) for both BKFV85 and CK92; they rely on the data from Site 747. The geological time scale has been revised (Berggren et al., in press; BKSA95) using a revised GPTS of Cande and Kent (1995; CK95). The GPTS of CK95 does not significantly differ from CK92 in the interval in question. Whereas the ages on the time scale have changed significantly from BKFV85 to BKSA95 in some intervals (e.g., the Eocene/ Oligocene boundary is nearly $3 \mathrm{~m}$.y. younger), we note that the comparisons presented here can be replotted vs. CK92/95 or BKSA95 using $\mathrm{Sr}$-isotopic data provided in Table 1.

Error analysis (e.g., equation 6 in Miller et al., 1991b) of the late Eocene-Oligocene regression (applicable from approximately 38 to $22.8 \mathrm{Ma}$; Oslick et al., 1994) demonstrates that a single analysis has an age uncertainty of about $\pm 1 \mathrm{~m}$.y. (at the $95 \%$ confidence interval; Miller et al., 1988). The Miocene regressions from 22.8 to $15.6 \mathrm{Ma}$ have age uncertainties of $\pm 0.6 \mathrm{~m}$.y. (for one analysis at the $95 \%$ confidence interval) to $\pm 0.4 \mathrm{~m} . \mathrm{y}$. (for three analyses at the $95 \%$ confidence interval), whereas the Miocene regressions from 15.2 to $\sim 10$ Ma have age uncertainties of \pm 1.2 (CK92) to \pm 1.4 (BKFV85) m.y. (for one analysis at the $95 \%$ confidence interval) to \pm 0.8 (CK92) to \pm 0.9 (BKFV85) m.y. (for three analyses at the $95 \%$ confidence interval). We assume that the theoretical maximum resolution is equivalent to our estimate of external precision $( \pm 0.000020)$ divided by the slopes of the regressions; this corresponds to age uncertainties of $\pm 0.6,0.3$, and $0.9 \mathrm{~m} . \mathrm{y}$. for the intervals $38-22.8,22.8-15.6$, and 15.6-10 Ma, respectively. 


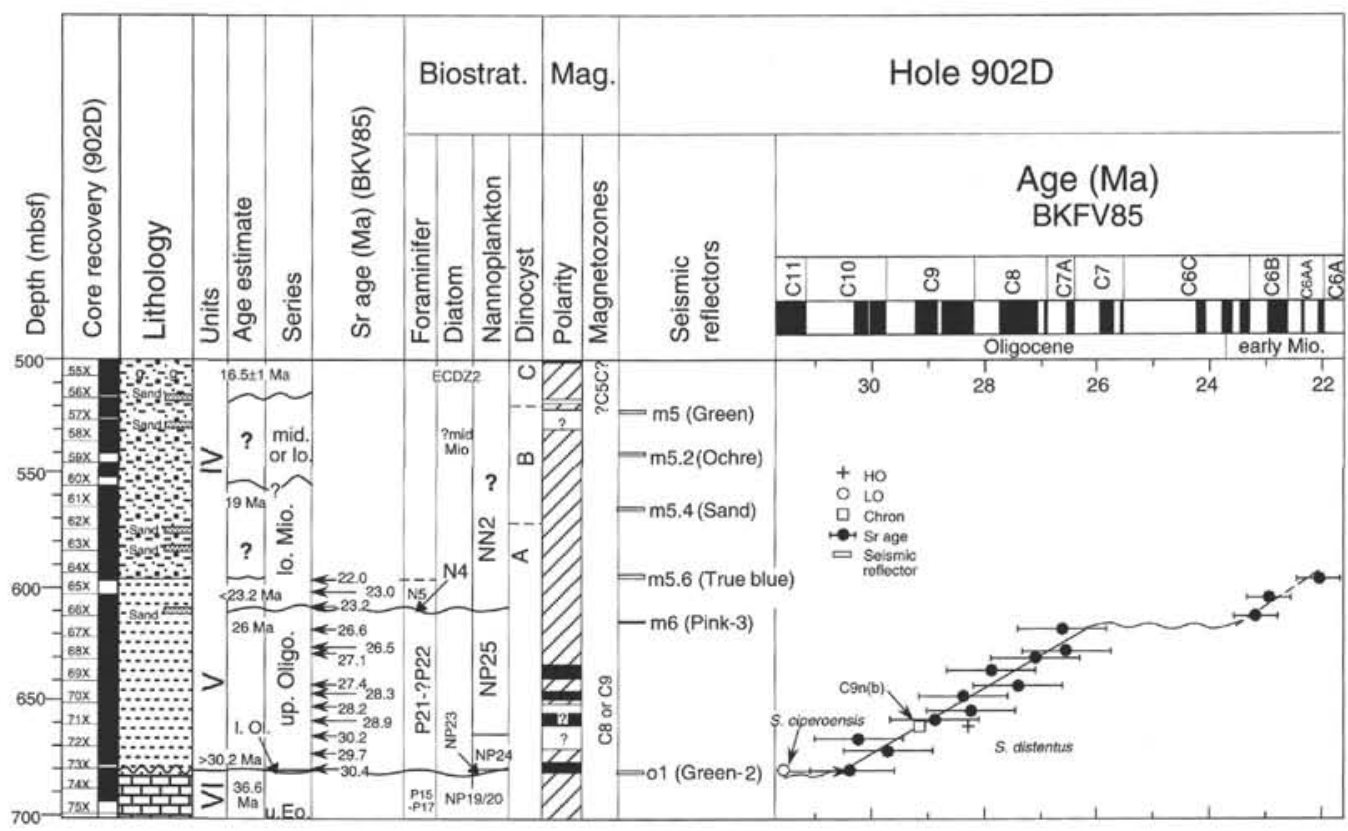

Figure 5. Integrated uppermost Eocene to lower middle Miocene section, Site 902. See Figure 2 caption for explanation.

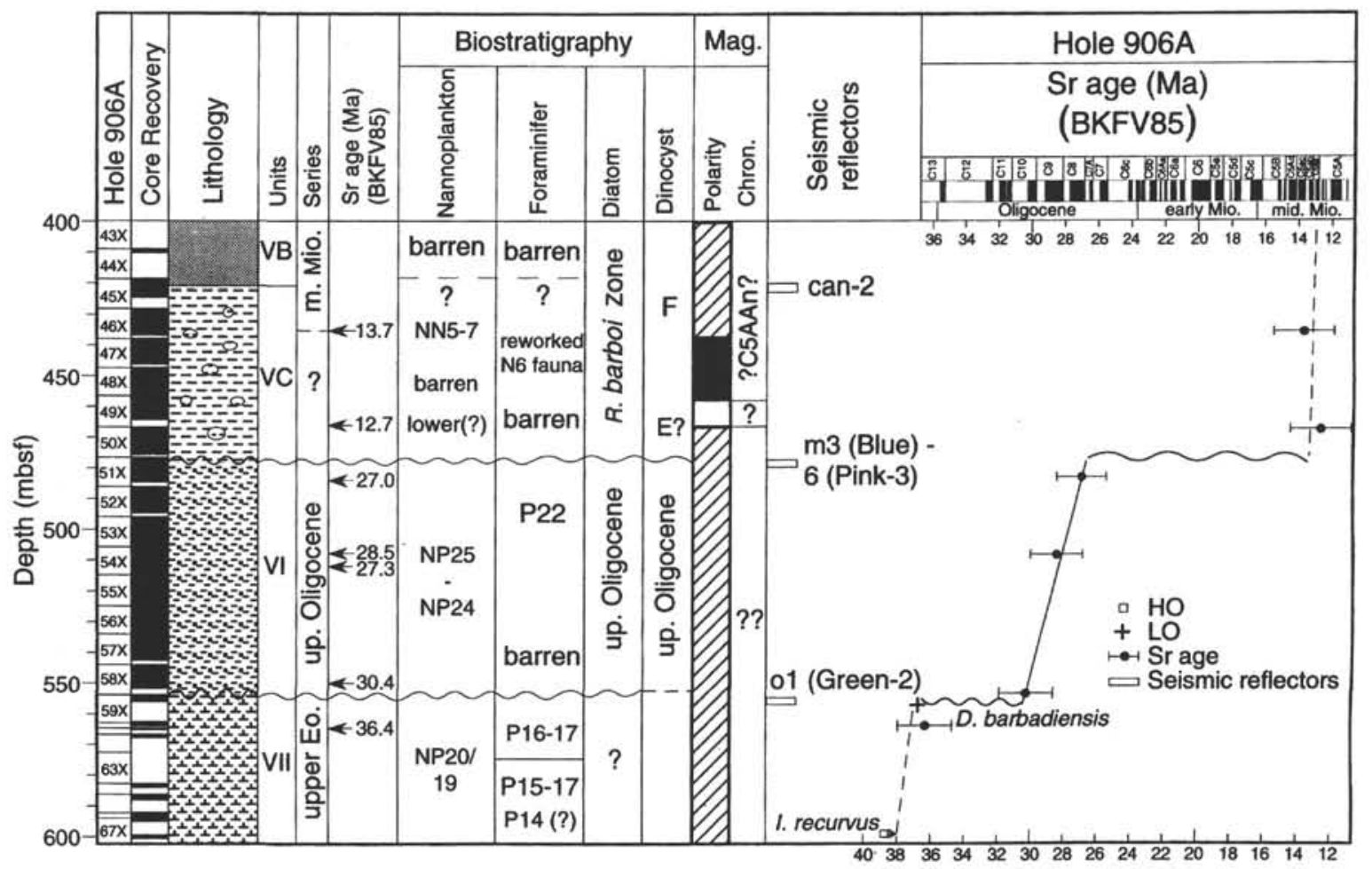

Figure 6. Integrated uppermost Eocene to lower middle Miocene section, Site 906. See Figure 2 caption for explanation. Late Eocene sedimentation rate is drawn from $38 \mathrm{Ma}$ (arbitrary level within lower Zone NP19/20; younger than LO Isthmolithus recurvus, 38.65; Miller et al., 1991a) to 37 Ma (arbitrary level in upper NP19/20; older than the HO Discoaster barbadiensis; 37.7 Ma). Miocene sedimentation rate is drawn from $13.5 \mathrm{Ma}$ at merged Reflector m3-m6 to 12.5 Ma at Reflector m2 (see "Discussion" section). Dashed line indicates uncertain age model. 


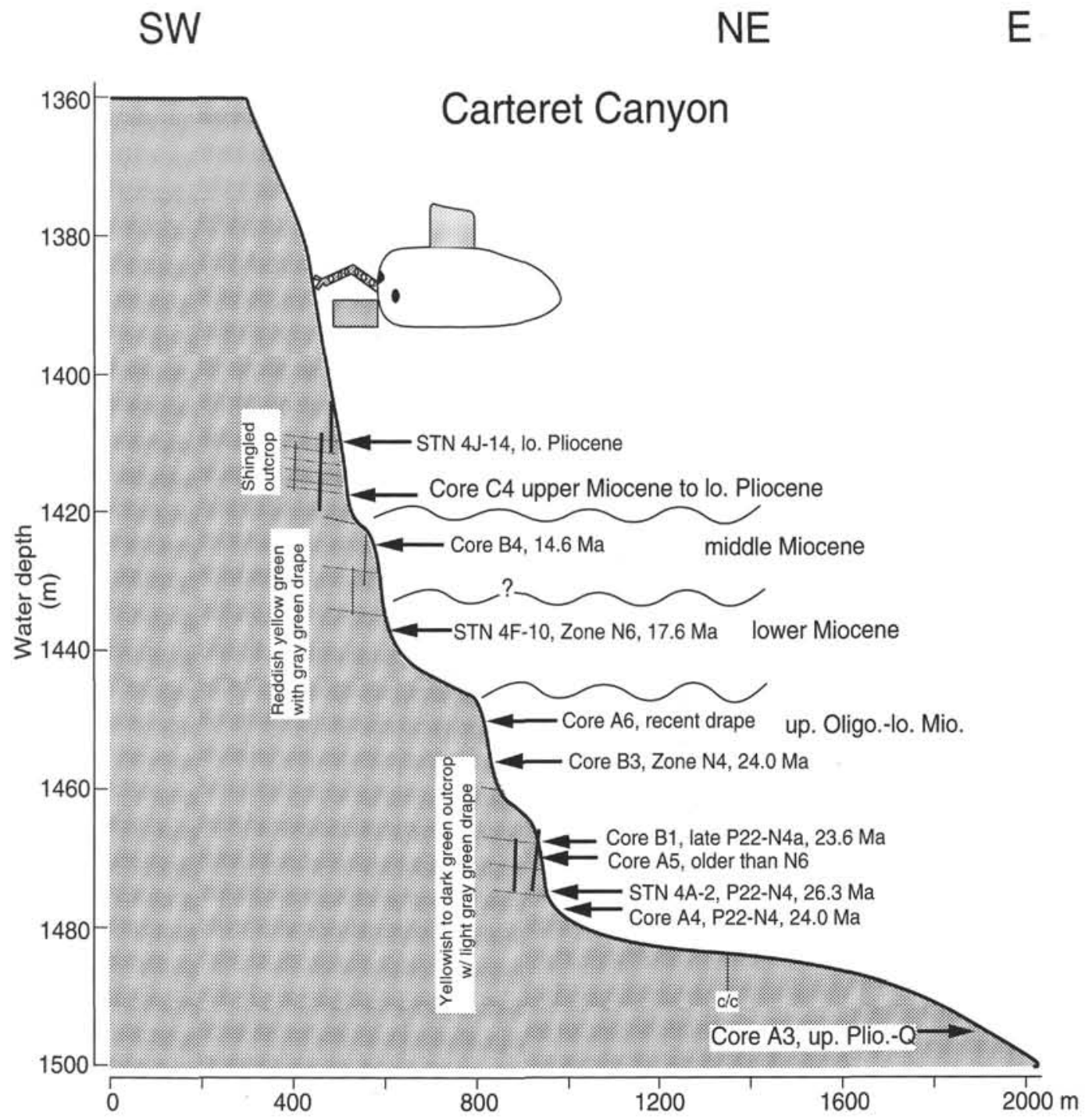

Figure 7. Carteret Canyon outcrop results, Alvin Dive 2169 (K. Miller and D. Twichell, observers) showing lithology, planktonic foraminifer zones, and Sr-isotopic age estimates (time scale of BKFV85). Section is based on Hydrosweep data (Fig. 1B, inset) and visual observations of the outcrop and corresponds to that between Stations 3 and 4 (Fig. 1B, inset). Wavy lines indicate paraconformities inferred from Sr-isotopic and biostratigraphic studies. Subhorizontal lines diagrammatically indicate bedding, nearly vertical heavy lines diagrammatically indicate Neptunian dikes. $\mathrm{c} / \mathrm{c}=$ change course.

\section{RESULTS}

\section{Leg 150 Boreholes}

\section{Site 904}

At Site 904, upper Oligocene siliciclastic clays disconformably overlie upper Eocene chalks, similar to the upper Oligocene/Eocene disconformities at Sites 902 and 903 (Mountain, Miller, Blum, et al., 1994). The upper Eocene is constrained by Zone P17, Zone NP1920 and ?Chron C15 (37.7-37.3 Ma), whereas the overlying sediments are clearly upper Oligocene (Zone NP24). The upper Oligocene ( 28 $\mathrm{Ma})$ to upper middle Miocene ( $11 \mathrm{Ma})$ section is well represented at Site 904 , and $29 \mathrm{Sr}$-isotopic analyses provide a relatively precise chronostratigraphic framework, especially when integrated with the planktonic foraminifer biostratigraphy of Snyder et al. (this volume), shipboard nannofossil studies, and shore-based magnetostratigraphic studies (Van Fossen and Urbat, this volume) (Fig. 2).

The upper Oligocene to lower lower Miocene section ( 28 to 18 $\mathrm{Ma})$ is continuous within the resolution of $\mathrm{Sr}$-isotopic stratigraphy
( \pm 1 m.y. for Oligocene; Miller et al., 1988 ; \pm 0.4 m.y. for early Miocene for three analyses at the $95 \%$ confidence interval; Oslick et al., 1994) (Figs. 2, 3). Comparison with the planktonic foraminifer biostratigraphy of Snyder et al. (this volume) is remarkably good for this section, with $\mathrm{Sr}$-isotopic ages generally falling within \pm 0.5 m.y. of the foraminifer age estimates (Fig. 3). Reflector m6 (Pink-3) is associated with the Oligocene/Miocene boundary, as it is at Sites 902, 903 , and 906.

There may be a short ( $<0.5$ m.y.) hiatus in the earliest Miocene, indicated by the possible absence of Zone NN1 and a very thin Zone N4. This possible gap is indiscernible using $\mathrm{Sr}$ isotopes. The marker for the top of Zone N4, the highest occurrence (HO) of Globorotalia kugleri $(21.8 \mathrm{Ma})$, is associated with $\mathrm{Sr}$-isotopic ages of 22.6 and $22.9 \mathrm{Ma}$, and it is possible that the $\mathrm{Sr}$-isotopic values are correct and the $\mathrm{HO}$ of Globorotalia kugleri may be slightly premature. We illustrate (Fig. 3) both interpretations (hiatus vs. diachrony), noting that the normal magnetozone in upper Core 150-904A-32X and lower Core $31 \mathrm{X}$ may be interpreted either as the base of C6An 1 (assuming a hiatus) or C6AAn (assuming diachrony of the $\mathrm{HO}$ of G. kugleri). 


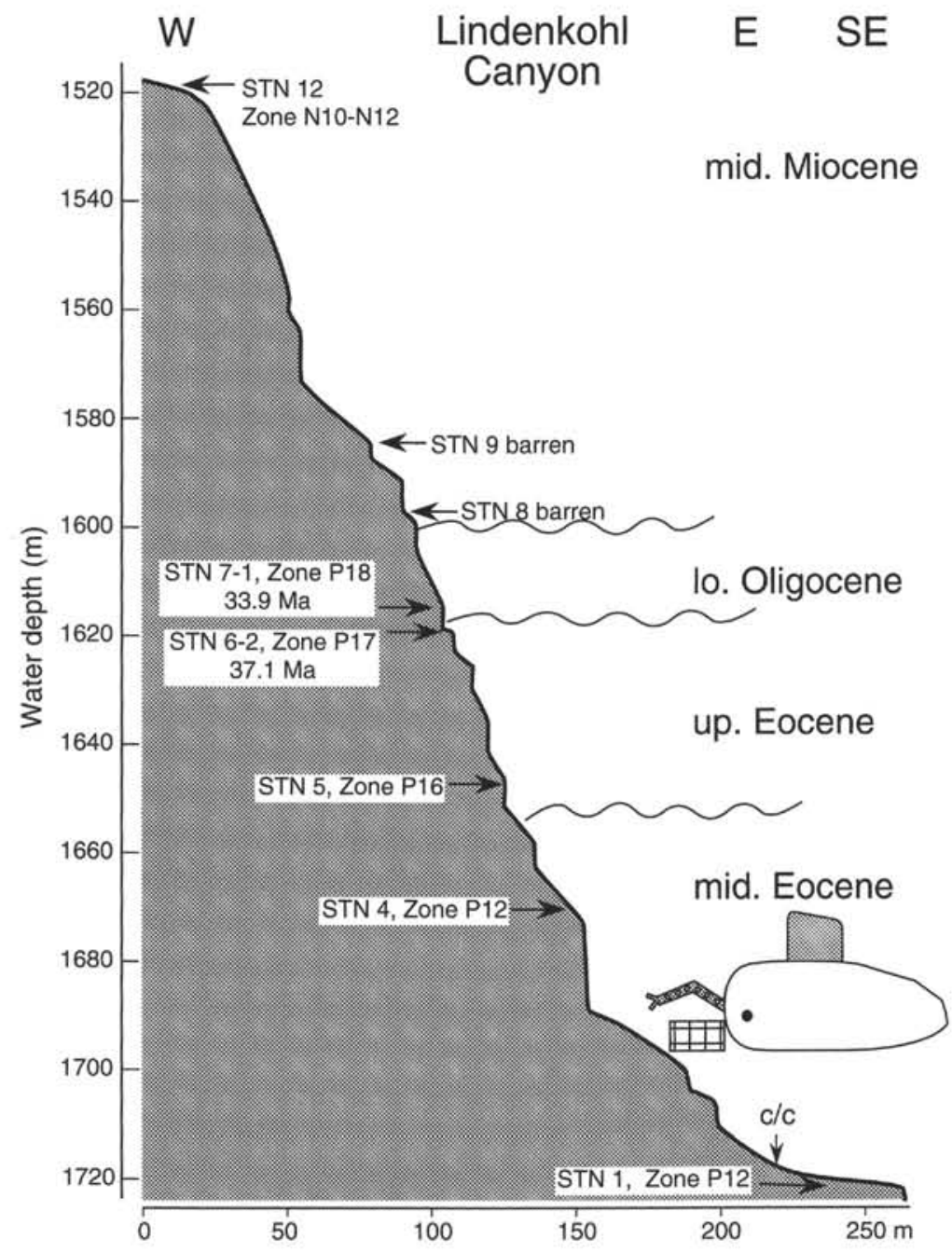

Figure 8. Lindenkohl Canyon outcrop results, Alvin Dive 2174 (B. Christensen and J. Wright, observers). Section drawn is based on Hydrosweep data (Fig. 1B, inset) and visual observations of the outcrop. Wavy lines indicate paraconformities inferred from $\mathrm{Sr}$-isotopic and biostratigraphic studies. $\mathrm{c} / \mathrm{c}=\mathrm{change}$ course.

Sr-isotopic age estimates indicate a hiatus (18.1-16.9 Ma; latest early Miocene) at the same level (between 256 and $259 \mathrm{mbsf}$ ) that shipboard nannofossil studies indicate a break between Zones NN2 and NN4. This is close to the shipboard correlation of Reflector m5 (Green), although there are large uncertainties in seismic correlations for the Reflectors m3-m5 interval at this site (Mountain, Miller, Blum, et al., 1994).

$\mathrm{Sr}$-isotopic age estimates also indicate an early middle Miocene hiatus (16.0-13.0 Ma) between 240 and $247 \mathrm{mbsf}$. This break is slightly below the break between Zones NN5 and NN7 based on shipboard studies. Planktonic foraminifer biostratigraphy cannot resolve this gap because of an interval with rare marker species. Reflector m3 (Blue) may correlate with this hiatus (Fig. 2), although the long hiatus implies that Reflectors $\mathrm{m} 3$ and $\mathrm{m} 4$ (Pink-2) are merged at this site. This may be the case, because the sequences bracketed by these reflectors thin and interfere approaching Site 904.

Sr-isotopic stratigraphy indicates that the lowest occurrences (LO) of Orbulina and Globorotalia peripheroacuta are delayed. These delayed LOs are caused by poor preservation between 200 and 240 mbsf. The younger (13-12.5 Ma) Sr-isotopic ages relative to the foraminifers cannot be ascribed to reworking of older material ana- lyzed for $\mathrm{Sr}$ isotopes. Although benthic foraminifer biofacies studies indicate that transported neritic material is common above $215 \mathrm{mbsf}$ (above upper Core 150-904A-24X), it is rare to absent in the interval from 240 to 220 mbsf (Katz and Miller, this volume).

Integration of $\mathrm{Sr}$-isotopic stratigraphy and magnetostratigraphy provides a good chronology for the middle middle Miocene at Site 904 (Fig. 3). By using the Sr isotopes to identify a thick reversed polarity zone as Chron C5Ar (Figs. 2, 3), we date Reflector m2 (Yellow-2; 12.6-12.5 Ma), which is apparently associated with no discernible hiatus at this site.

Three Sr-isotopic analyses from Cores 150-904A-18X and 19X indicate middle Miocene ages, consistent with the shipboard diatom and dinocyst biostratigraphy. However, these samples are dominated by reworked and/or transported benthic foraminifers (Katz and Miller, this volume), and we ascribe the older ages to reworked middle Miocene material contained in upper Miocene sediments. Planktonic foraminifers and nannofossils indicate the presence of upper Miocene ( $~ 8 \mathrm{Ma})$ strata above the probable level of Reflector $\mathrm{ml}$ (Tuscan; $180.3 \mathrm{mbsf}$ ). Strata underlying Reflector $\mathrm{ml}$ are dated as $\sim 11.3$ $\mathrm{Ma}$ and lowermost Chronozone C5r, establishing a maximum age for $\mathrm{ml}$. The overlying sediments (147.3-180.3 mbsf) are tentatively as- 
Table 2. Sr-isotopic data for foraminifers in slope outcrops and non-ODP boreholes.

\begin{tabular}{|c|c|c|c|c|c|c|c|}
\hline & & & & & & & Biozone \\
\hline & Sample & $\begin{array}{c}\text { Water } \\
\text { depth }(m)\end{array}$ & ${ }^{87} \mathrm{Sr} r^{86} \mathrm{Sr}$ & Error & $\begin{array}{c}\text { Age (Ma) } \\
\text { (BKFV85/CK92) }\end{array}$ & $\begin{array}{l}\text { Planktonic } \\
\text { foraminifers }\end{array}$ & Radiolarians \\
\hline $\begin{array}{l}\text { Alvin san } \\
\text { Dive 216 }\end{array}$ & $\begin{array}{l}\text { aples } \\
0\end{array}$ & & & & & & \\
\hline Station & & 1500.0 & & & & u. $\mathrm{P} 22-\mathrm{N} 4$ & \\
\hline $\begin{array}{l}\text { Station } \\
\end{array}$ & & 1481.0 & & & & N8-9 & \\
\hline $\begin{array}{r}\text { Dive } 216 \\
\text { Station }\end{array}$ & ${ }_{4}^{9}$ J, Sample 14 & 1410.0 & & & & N18-20 & $\begin{array}{l}\text { "7" lo. } \\
\text { D. petterssoni }\end{array}$ \\
\hline Station & $4 \mathrm{I}$, Core $\mathrm{C} 4$ & 1418.0 & & & & N17-19 & "8" lo. D. alata \\
\hline Station & $4 \mathrm{H}$, Core B4 & 1425.0 & 0.708810 & 0.000006 & $14.58 / 14.44$ & m. Miocene & "8" lo. D. alata \\
\hline Station & 4F, Sample 10 & 1438.0 & 0.708674 & 0.000006 & $17.57 / 17.29$ & N6 & $" 9 "$ C. costata \\
\hline $\begin{array}{l}\text { Station } \\
\text { Station }\end{array}$ & $\begin{array}{l}\text { 4E, Core A6 } \\
\text { 4D, Core B3 }\end{array}$ & $\begin{array}{l}1450.0 \\
1456.0\end{array}$ & 0.708263 & 0.000006 & 23.97/24.09 & $\begin{array}{l}\text { u. Pliocene-Holocene } \\
\text { u. P22-N4a }\end{array}$ & " 13 " L. elongata \\
\hline & & & 0.708275 & 0.000004 & $23.62 / 23.85$ & & \\
\hline $\begin{array}{l}\text { Station } \\
\text { Station }\end{array}$ & $\begin{array}{l}4 \text { C, Core B1 } \\
4 \text { C, Core A5 }\end{array}$ & $\begin{array}{l}1468.0 \\
1470.0\end{array}$ & 0.708182 & 0.000005 & $26.30 / 25.66$ & $\begin{array}{l}\text { u. } \mathrm{P} 22-\mathrm{N} 4 \mathrm{a} \\
>\mathrm{N} 6\end{array}$ & "13" L elongata \\
\hline Station & 4B. Core A4 & 1475.0 & & & & ?u. P22-N4a & "14-13" up. D. ateuchus - L. elongata \\
\hline Station & 4 A, Sample 2 & 1477.0 & 0.708262 & 0.000028 & $24.00 / 24.11$ & u. $\mathrm{P} 22-\mathrm{N} 4 \mathrm{a}$ & "14-13" up. D. ateuchus- $L$ elongata \\
\hline Station & 3, Core A3 & 1497.0 & & & & Holocene & \\
\hline $\begin{array}{l}\text { Station } \\
\text { Station }\end{array}$ & $\begin{array}{l}\text { 3, Core A2 } \\
1 \text {, Core A1 }\end{array}$ & $\begin{array}{l}1541.0 \\
1547.0\end{array}$ & & & & $\begin{array}{l}\text { Holocene } \\
\text { Holocene }\end{array}$ & \\
\hline Dive 217 & & & & & & & \\
\hline Station & 5, Core B3 & 1458.0 & & & & P19 & " $15 " T$. tuberosa \\
\hline Station & 6. Core B2 & 1450.0 & & & & ?N4 & "13" L. elongata \\
\hline Station & 7, Core $\mathrm{Cl}$ & 1425.0 & & & & & Mixed mid. Miocene and Holocene \\
\hline Dive 217 & & & & & & & \\
\hline Station & 12 , Core B1 & 1515.6 & & & & $\mathrm{~N} 10-12$ & \\
\hline Station & 9, Core B2 & 1588.0 & & & & Barren & \\
\hline Station & 8. Core B3 & 1595.0 & & & & Barren & \\
\hline Station & 7 , Core $\mathrm{C} 4$ & 1615.6 & 0.707917 & 0.000005 & $33.92 / 32.22$ & P18 & "16c" T. tuberosa \\
\hline Station & 6, Core C3 & 1619.0 & 0.707806 & 0.000004 & $37.11 / 35.25$ & P17 & "16b" C. ornata \\
\hline Station & 5. Sample 1 & 1647.0 & & & & P16 & \\
\hline Station & 4. Core C2 & 1699.0 & & & & $\mathrm{P} 12$ & \\
\hline Station & 1, Core B4 & 1723.5 & & & & P12 & \\
\hline Bore & hole samples & $\begin{array}{l}\text { Depth } \\
\text { (mbsf) }\end{array}$ & & & & & \\
\hline Site 61 & & & & & & & \\
\hline 16-CC & & 135.9 & 0.707848 & 0.000006 & $35.90 / 34.10$ & P18 & \\
\hline $17-4,6$ & $0-64 \mathrm{~cm}$ & 141.3 & 0.707804 & 0.000006 & $37.70 / 35.31$ & P17 & \\
\hline $18-4,6$ & $0-64 \mathrm{~cm}$ & 150.8 & 0.707826 & 0.000009 & $36.54 / 34.70$ & P17 & \\
\hline $19-3,6$ & $0-64 \mathrm{~cm}$ & 158.8 & 0.707794 & 0.000014 & $37.46 / 35.58$ & P17 & \\
\hline ASP 14 & Water depth: 11 & $1 \mathrm{~m})$ & & & & & \\
\hline (ftbsl) & (mbsl) & $\begin{array}{l}\text { Depth } \\
\text { (mbsf) }\end{array}$ & & & & & \\
\hline 4282 & 1305.4 & 114.2 & & & & G. conomiozea & \\
\hline 4655 & 1419.1 & 227.9 & & & & G. fohsi lobata/robusta & \\
\hline 4658 & 1420.2 & 229.0 & & & & G. fohsi lobata/robusta & \\
\hline 4822 & 1470.2 & 279.0 & & & & G. fohsi peripheronda & \\
\hline 4825 & 1470.9 & 279.7 & 0.708713 & 0.000014 & $17.01 / 16.72$ & G. miozea & \\
\hline 4827 & 1471.6 & 280.4 & 0.708651 & 0.000008 & $17.91 / 17.63$ & G. miozea & \\
\hline 4829 & 1472.2 & 281.0 & 0.708649 & 0.000018 & $17.94 / 17.65$ & G. miozea & \\
\hline 4830 & 1472.7 & 281.5 & 0.708684 & 0.000006 & $17.43 / 17.14$ & G. miozea & \\
\hline 4839 & 1475.2 & 284.0 & 0.708668 & 0.000013 & $17.66 / 17.38$ & G. miozea & \\
\hline 4841 & 1475.8 & 284.6 & 0.708694 & 0.000006 & $17.29 / 17.00$ & G. miozea & \\
\hline ASP 15 & Water depth: 14 & $3 \mathrm{~m})$ & & & & & \\
\hline (ftbsl) & (mbsl) & $\begin{array}{l}\text { Depth } \\
\text { (mbsf) }\end{array}$ & & & & & \\
\hline 4956 & 1511.0 & 18.1 & & & & G. conomiozea & \\
\hline 4958 & 1511.5 & 18.6 & 0.708875 & 0.000018 & $11.66 / 11.99$ & G. fohsi/robusta & \\
\hline 4960 & 1512.1 & 19.2 & & & & & \\
\hline 5018 & 1529.9 & 37.0 & 0.708538 & 0.000010 & $19.54 / 19.32$ & C. dissimilis & \\
\hline 5021 & 1530.9 & 38.0 & & & & C. dissimilis & \\
\hline 5024 & 1531.7 & 38.8 & & & & C. dissimilis & \\
\hline 5026 & 1532.2 & 39.3 & & & & C. dissimilis & \\
\hline 5096 & 1553.6 & 60.7 & 0.707886 & 0.000007 & $34.81 / 33.07$ & T. cerroazulensis & \\
\hline
\end{tabular}

Notes: BKFV85 = Berggren, Kent, Flynn, and van Couvering (1985). CK92 = Cande and Kent (1992). Outcrop radiolarian zonations are after A. Palmer-Julson (pers. comm., 1990). Site 612 data are after Miller et al. (1991a). ftbsl = feet below sea level. mbsl = meters below sea level. ASP-14 and -15 foraminiferal biostratigraphy is after Melillo (1985).

signed to Chronozone C4Ar ( 8.9-8.3 Ma) (Van Fossen and Urbat, this volume).

\section{Site 903}

Although we analyzed 27 samples for Sr isotopes at Site 903, the late Oligocene to middle Miocene chronology is not as well constrained as at Site 904 because of the lack of planktonic foraminifer biostratigraphic control and magnetostratigraphy below about 800 mbsf (Fig. 4). Nevertheless, integration of Sr-isotopic age estimates with shipboard nannofossil zones provides a preliminary chronology that delineates at least three Oligocene to middle Miocene hiatuses and a possible fourth gap.

Nannofossil studies at Site 903 indicate that middle Oligocene Zone NP23 disconformably overlies upper Eocene Zone NP19-20, with a possible disconformity between Zones NP23 and NP25 (i.e., 
Zone NP24 was not identified on the ship; Mountain, Miller, Blum, et al., 1994; Fig. 4). We analyzed only five samples from the Oligocene section for $\mathrm{Sr}$ isotopes. Three analyses at $1027-1036 \mathrm{mbsf}$ (29.6-28.2 Ma; Table 1) yield ages that are equivalent to Zone NP24, indicating that this zone may be present between samples identified as Zones NP23 and NP25. Thus, we make a conservative interpretation (Fig. 4) of continuous late early to early late Oligocene sedimentation between 1064 ( 32 Ma based on extrapolation of sedimentation rates within Zone NP23; Fig. 4) and 1007 mbsf (27.8 Ma based on $\mathrm{Sr}$ isotopes). Although the resulting sedimentation rate $(\sim 13.6 \mathrm{~m} /$ m.y.) is much lower than the Miocene rates (e.g., $>33 \mathrm{~m} / \mathrm{m} . \mathrm{y}$. between 16.6 and 12.1 Ma at Site 903; Fig. 4), it is similar to Oligocene rates at Sites $902(13 \mathrm{~m} / \mathrm{m} . \mathrm{y}$.$) and 904(7 \mathrm{~m} / \mathrm{m} . \mathrm{y}$.$) .$

Sr-isotopic stratigraphy indicates a possible break between 1027 mbsf (28.2 Ma) and $1003 \mathrm{mbsf}(24.0 \mathrm{Ma})$ with a second possible break between $1003 \mathrm{mbsf}$ and $1000 \mathrm{mbsf}(22.2 \mathrm{Ma})$. The available data cannot confirm that there are actually two breaks (i.e., additional data near $1003 \mathrm{mbsf}$ are needed), but indicate that there is at least one definite hiatus near the Oligocene/Miocene boundary. Nannofossils also indicate that the Oligocene/Miocene boundary is disconformable, with Zone NN1 missing; this level (1005 mbsf) is associated with a dolomite-cemented bed that may mark the disconformity and is correlated with Reflector m6 (Pink-3) (Mountain, Miller, Blum, et al., 1994).

Sr-isotopic analyses reveal two groups of ages in the lower Miocene section at Site 903: the first is a group of 22.2-21.7 Ma (five analyses) between 1000 and $973 \mathrm{mbsf}$, and the second is a group of 18.4-18.1 Ma (five analyses) between 950 and $910 \mathrm{mbsf}$. Although there is a $23-\mathrm{m}$ data gap between the groups, the tight groupings and sedimentation rate diagram (Fig. 4) indicate a probable hiatus (indicated as 21-18.3 Ma, Fig. 4). We suggest that it is associated with Reflector m5.4 (Sand) at this site (at about 960 mbsf; Fig. 4), dating it as 21-18.3 Ma. The interpretation of the hiatus also implies high (>100 m/m.y.) sedimentation rates between 950 and $910 \mathrm{mbsf}$; these high rates are reasonable and may represent the beginning of high sedimentation rates at Site 903 (Fig. 4).

Shipboard nannofossil studies indicated a gap near 925 mbsf at Site 903, with Zone NN3 missing. This hiatus (shown as 19-17.4 Ma, Fig. 4) apparently correlates with Reflector 5.2 (Ochre). Sr-isotopic data do not record this possible hiatus. $\mathrm{Sr}$ isotopes indicate that $\mathrm{Re}$ flector m5.2 is $\sim 18.2 \mathrm{Ma}$. Further nannofossil and Sr-isotopic studies are needed to determine if a hiatusis occurred in this interval.

Sr-isotopic age estimates indicate a clear hiatus between 18.2 (910 mbsf) and $16.45 \mathrm{Ma}$ (mean of two analyses at 901 and 904 mbsf). This hiatus spans the early/middle Miocene boundary and correlates with Reflector $\mathrm{m} 5$ (Green) (Fig. 4). The age estimate for this reflector is similar to that at Site 904 (Fig. 3).

$\mathrm{Sr}$ isotopes indicate no discernible gaps between $~ 16.4$ (901-904 $\mathrm{mbsf})$ and $12.5 \mathrm{Ma}$ (804 mbsf). By interpolating between the Sr-isotopic age estimates at the base of this section and a magnetochronologic age 13.0 Ma for the base of the normal magnetozone (767-791 mbsf) that we correlate to Chron C5AAn (Fig. 4), we obtain age estimates of $\sim 14.8 \mathrm{Ma}$ for Reflector $\mathrm{m} 4$ (Pink-2) and $\sim 13.6 \mathrm{Ma}$ for Reflector $\mathrm{m} 3$ (Blue) (Fig. 4). Alternatively, assuming the same sedimentation rate as the sections above and below, a hiatus from 14.9 to 13.8 Ma could be associated with Reflector $\mathrm{m} 4$ at this site (shown as dashed lines, Fig. 4). In addition, the age of Reflector $\mathrm{m} 3$ (Blue) could be as young as $\sim 12.8 \mathrm{Ma}$ at Site 903 if the normal magnetozone from 767-791 mbsf correlates to C5Ar.ln or .2n (Van Fossen and Urbat, this volume); however, this young age is contradicted by the Reflector m3 age of >13.0 Ma at Sites 904 and 906 (see "Discussion"). Reflector m2 (Yellow-2) has an age estimate of $\sim 12.5 \mathrm{Ma}$ based on its position in Chronozone C5Ar (Fig. 4), although the top of this chronozone is poorly defined at this site. These are the best age estimates available for these reflectors.

We obtained a single analysis from the upper middle Miocene section at Hole 903A. This analysis at 665 mbsf yields a middle mid- dle Miocene age of $14.5 \mathrm{Ma}$ (Table 1). This is clearly contradicted by the planktonic foraminiferal and dinocyst data that indicate the section is upper middle Miocene and by the Sr-isotopic data below, which also indicate that the section is younger than $12.5 \mathrm{Ma}$. We attribute the older age to reworking of foraminifers. This is supported by the benthic foraminifer data, which indicate that this section consists entirely of transported thanatofacies (Katz and Miller, this volume).

\section{Site 902}

We obtained $12 \mathrm{Sr}$-isotopic analyses for the Oligocene and three for the lower Miocene at Site 902 that show excellent agreement with the shipboard nannofossil and paleomagnetic studies (Fig. 5). Nannofossils indicate a break between upper Eocene Zones NP19-20 $(>36.7 \mathrm{Ma})$ and a single sample assigned to lower Oligocene Zone NP23 ( $>30.2 \mathrm{Ma}$ according the BKFV85 time scale; however, note that the base of Zone NP24 = HO S. distentus may be older; M.-P. Aubry, pers. comm., 1994). Sr isotopes indicate that deposition resumed at about $30.4 \mathrm{Ma}$ (average of two analyses at $677 \mathrm{mbsf}$ ) in the latest early Oligocene, consistent with the nannofossil results. Sr isotopes and nannofossils do not indicate any gaps in the Oligocene until about 27-26 Ma, when there was a hiatus until about 23.2 Ma (Zone NN2; earliest Miocene). This hiatus is correlated with Reflector m6 (Pink-3). Reflector m5.6 (True blue) cannot be distinguished with the available seismic data from the underlying Reflector m6; given the shipboard correlation of Reflector m5.6 at $595 \mathrm{mbsf}$, Sr isotopes date it as $\sim 22 \mathrm{Ma}$.

\section{Site 906}

We analyzed six samples for Sr-isotopic studies at Site 906 (Fig. 6). The sole Eocene sample yielded an age of $36.4 \mathrm{Ma}$, consistent (within the errors) with assignment to upper Eocene Zone NP19-20 (>36.7 Ma). Three Oligocene samples from 550 to 483 mbsf range from 30.4 (latest early Oligocene) to $27.0 \mathrm{Ma}$, which is virtually identical to the ages of the Oligocene section at Site 902. The similar ages are remarkable considering the error estimates provided by statistics (Oslick et al., 1994), and suggests that our stratigraphic resolution actually approaches theoretical resolution (i.e., $\pm 0.6 \mathrm{~m}$.y. for the Oligocene, \pm 0.3 k.y. for the middle Miocene, and \pm 0.9 m.y for the middle Miocene). The similarity between the Oligocene sections is not surprising because Site 902 is only $3.3 \mathrm{~km}$ from Site 906 . However, the section at Site 906 is thicker than at Site 902 (66 vs. $47 \mathrm{~m}$ ), and thus the sedimentation rates are higher ( $20 \mathrm{vs} .13 \mathrm{~m} / \mathrm{m}$.y.). Farther upsection, two Miocene ages of 13.7 and $12.7 \mathrm{Ma}$ are stratigraphically inverted (Fig. 6), but are consistent within the errors of each other and with the ages of the section obtained by seismic stratigraphic correlation (i.e., approximately the age of Reflector m3,13.6 Ma, but older than Reflector m2, 12.5 Ma).

\section{Alvin Samples and Other New Jersey Slope Boreholes}

Farre and Ryan (1987) mapped probable outcrops of Tertiary strata in this region of the New Jersey slope (Fig. 1B). Drilling at Site 612 (Fig. 1) failed to sample approximately $50-100 \mathrm{~m}$ of lowermost Oligocene to middle Miocene strata that are exposed on the walls of Carteret Canyon (Miller et al., 1987b). Oligocene-Miocene slope outcrops were first sampled in the Amphitheater by Alvin Dive 2160 in September 1989 (Fig. 1B; Table 2). Problems developed with the Alvin penetrators, rendering subsequent detailed sampling of the Amphitheater impossible. We returned with Alvin in December 1989 to sample canyon outcrops. Sampling was focused on outcrop areas with steep bathymetric gradients detected in the SeaBeam data of Carteret, Lindenkohl, and lower Berkeley canyons. Although these efforts to sample and date the outcropping strata were successful, they provide only a glimpse of the record of Oligocene to Miocene 


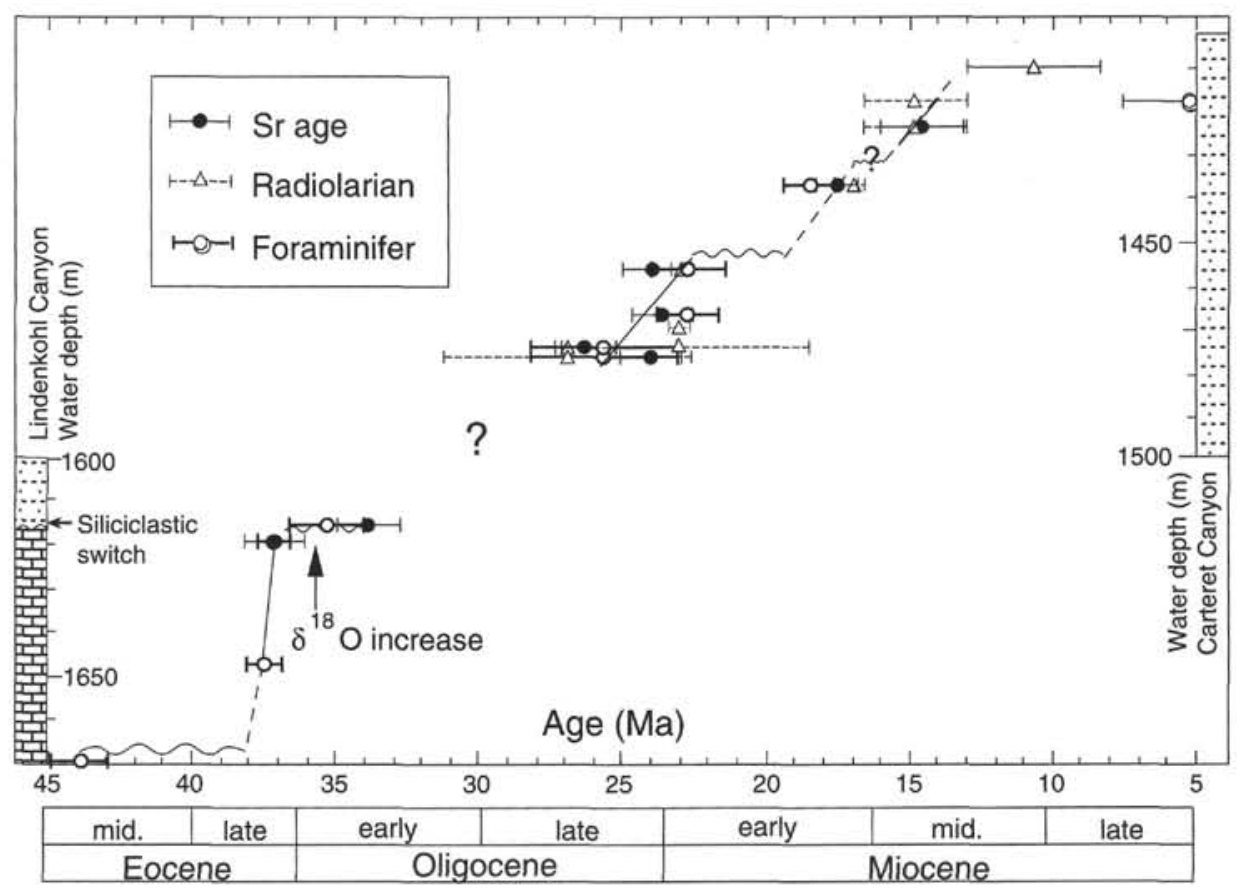

Figure 9. Age-depth diagram for Lindenkohl and Carteret Canyon outcrops sections, showing generalized lithostratigraphy and Sr-isotopic, foraminifer, and radiolarian age estimates (Table 2). The timing of the global Oil oxygen isotopic increase of Miller et al. (1991c) is shown by arrow. Dashed line indicates uncertain age model.

deposition because the sections thin downdip toward outcrop. For example, Carteret Canyon outcrops expose $52 \mathrm{~m}$ of Oligocene to middle Miocene strata, whereas drilling at Site 904 ( 2.4 nmi updip) recovered nearly $160 \mathrm{~m}$ of these strata and at Site 903 recovered nearly $500 \mathrm{~m}$. Nevertheless, the slope outcrops document hiatuses that correlate with those found in the boreholes (Figs. 7-10) and precisely date a major regional change in depositional environment in the earliest Oligocene that was not well constrained in the Leg 150 boreholes.

In Carteret Canyon (Dive 2169, Fig. 7), Tertiary strata are exposed in nearly vertical walls broken by broad terraces and narrower benches. Terraces and benches are heavily draped by recent pelagic oozes that obscure Tertiary subcrops except in cliff walls. The outcrops have subhorizontal regional dips (Fig. 7). Neptunian sandstone dikes intrude the Tertiary outcrops, infilling joints that range from nearly vertical to subhorizontal in orientation. These dikes intrude strata as young as the lower Pliocene (Fig. 7), thus dating the maximum time of intrusion of the joints.

Carteret Canyon Dive 2169 sampled a 30-m-thick uppermost Oligocene to lowermost Miocene section $(\sim 26-23.8 \mathrm{Ma})$, a thin lower to middle Miocene section $(\sim 20 \mathrm{~m}, \sim 18-15 \mathrm{Ma})$, and a thin upper Miocene to Pliocene section. These strata contain in situ lower bathyal sediments (Figs. 7, 9). The uppermost Oligocene to lowermost Miocene section consists of yellowish to dark green silty clays. Upper lower to middle Miocene strata are reddish-yellow-green silty clays. Uppermost Miocene-Pliocene strata have a shingled appearance; small outcrops of shingled sediments that dip subparallel to seafloor were observed in the thalweg of the modern canyon (e.g., Station 3 , Figs. 1B, 7). These small shingled outcrops in the thalweg may be slide blocks of upper Miocene and younger strata.

We were able to date the Carteret Canyon strata using Sr-isotopic stratigraphy and biostratigraphy. In general, the Sr-isotopic ages (Table 2), planktonic foraminiferal zones (Table 2), and radiolarian zones (Table 2; A. Palmer, pers. comm., 1990) agree quite well (Fig. 9). Carteret Canyon outcrops recorded a distinct hiatus from 23.8 to $\sim 18 \mathrm{Ma}$ (early Miocene); two possible hiatuses occurred from $\sim 17$ to $15 \mathrm{Ma}$ (early to middle Miocene) and from $\sim 14.5$ to $<5 \mathrm{Ma}$ (middle Miocene to early Pliocene) (Figs. 7, 9). Two of these hiatuses are associated with distinct terraces/benches noted in the outcrop (Fig. 7), providing physical evidence for these inferred unconformities.

The Lindenkohl Canyon outcrop (Dive 2174) provided a thick Eocene section, a thin Oligocene section, and a nearly barren middle Miocene section (Fig. 8). The stratigraphy of the Eocene chalks is consistent with that at Site 612 (Miller and Hart, 1987) and Sites 902, 903, and 904 (Mountain, Miller, Blum, et al., 1994), with a disconformity separating Zone P12 (middle Eocene; 1669 m; Table 2) from Zone P16 (upper Eocene; 1647 m; Table 2). This indicates a long hiatus from $\sim 44$ to $38 \mathrm{Ma}$, as observed at Site 612 (e.g., Miller and Hart, 1987). Zone P17 is tentatively recognized in tan chalks ( $1619 \mathrm{~m}$; Table 2) by forms transitional to Turborotalia cerroazulensis cunialensis; this sample has a Sr-isotopic age estimate of latest Eocene (37.1 $\pm 1 \mathrm{Ma}$; Table 2). Lower Oligocene sediments (1615.6 m; Table 2) consist of dark green silty clays overlying the tan Eocene chalks; they are assigned to Zone P18 based on the presence of Pseudohastigerina (>34.0 Ma) above the $\mathrm{HO}$ of Turborotalia cerroazulensis ssp. and have a Sr-isotopic age estimate of $33.9 \mathrm{Ma}$ (Table 2). This indicates a hiatus from $\sim 37$ to $34 \mathrm{Ma}$. Two ?middle Miocene samples (Station 8, Sample 1, Core B3, 1595 m; Station 9, Sample 1, Core B2, 1588 $\mathrm{m}$ ) consisting of orange to dark green platy micaceous hard mud were devoid of foraminifers but contain radiolarians; these are lithologically similar to piston core samples (AII 120-02 PC16) obtained in the thalweg of Lindenkohl Canyon that are dated as Zone N6 or older. They are overlain by a sample that contains middle Miocene (Zones N10-12, undifferentiated; Station 12, Sample 1, Core B1, 1538 m) transported neritic benthic foraminifers (Uvigerina elongata, $\mathrm{Bu}$ liminella gracilis, Nonionella pizarrensis, Buliminella elegantissima, Buccella sp., among others).

The most interesting result from Lindenkohl Canyon outcrop was the precise dating of a change from carbonate-dominated sedimentation in the late Eocene to siliciclastic deposition in the earliest Oli- 
Table 3. Sr-isotope-based age estimates of Oligocene-middle Miocene seismic reflectors, New Jersey continental slope.

\begin{tabular}{|c|c|c|c|c|c|}
\hline Reflector/color & 902 & 903 & 904 & Series & Best age estimate \\
\hline $\begin{array}{l}\mathrm{ml} \text { Tuscan* } \\
\text { Above } \\
\text { Below }\end{array}$ & & $\begin{array}{l}\mathrm{C} 5 \mathrm{r} 2, \sim 10.5-11.0 \mathrm{Ma} \\
\mathrm{C} 5 \mathrm{r} 2, \sim 10.5-11.0 \mathrm{Ma}\end{array}$ & $\begin{array}{l}\text { ?C4Ar, } 8.3 \mathrm{Ma} \\
\text { lower C5r, } 11.3 \mathrm{Ma}\end{array}$ & upper middle Miocene & $? 10.5-11.3 \mathrm{Ma}$ \\
\hline $\begin{array}{l}\mathrm{m} 2 \text { Yellow-2* } \\
\text { Above } \\
\text { Below }\end{array}$ & - & $\mathrm{C} 5 \mathrm{Ar}, \sim 12.5-12.6 \mathrm{Ma}$ & $\begin{array}{l}0.708865,12.1 \mathrm{Ma} \\
0.708846,13.0 \mathrm{Ma}\end{array}$ & upper middle Miocene & $\begin{array}{l}12.5-12.6 \mathrm{Ma} \\
\text { Based on interpolation of } \\
\text { sedimentation rate }\end{array}$ \\
\hline $\begin{array}{l}\text { m3 Blue* } \\
\text { Above } \\
\text { Below }\end{array}$ & $\overline{-}$ & $\begin{array}{l}0.708857,12.5 \mathrm{Ma} \\
0.708857,12.5 \mathrm{Ma}\end{array}$ & $\begin{array}{l}0.708846,13.0 \mathrm{Ma} \\
0.708786,16.0 \mathrm{Ma}\end{array}$ & upper middle Miocene & $\begin{array}{l}13.6 \mathrm{Ma} \\
\text { Based on interpolation of sed. rate } \\
\text { Range } 12.8-13.6 \mathrm{Ma}\end{array}$ \\
\hline $\begin{array}{l}\text { m4 Pink-2* } \\
\text { Above } \\
\text { Below }\end{array}$ & $\overline{-}$ & $\begin{array}{l}0.708835,13.5 \mathrm{Ma} \\
0.708785,15.7 \mathrm{Ma}\end{array}$ & Merged with $\mathrm{m} 3$ & middle middle Miocene & $\begin{array}{l}14.8 \mathrm{Ma} \\
\text { Based on interpolation of sed. rate } \\
\text { Range } 13.8-15.0 \mathrm{Ma}\end{array}$ \\
\hline $\begin{array}{l}\mathrm{m} 5 \text { Green* } \\
\text { Above } \\
\text { Below }\end{array}$ & $\overline{-}$ & $\begin{array}{l}0.708761,16.3 \mathrm{Ma} \\
0.708633,18.2 \mathrm{Ma}\end{array}$ & $\begin{array}{l}0.708724,16.9 \mathrm{Ma} \\
0.808636,18.1 \mathrm{Ma}\end{array}$ & lower/middle Miocene boundary & $16.3-18.0 \mathrm{Ma}$ \\
\hline $\begin{array}{l}\mathrm{m} 5.2 \text { Ochre** } \\
\text { Above } \\
\text { Below }\end{array}$ & $\overline{-}$ & $\begin{array}{l}0.708629,18.2 \mathrm{Ma} \\
0.708625,18.3 \mathrm{Ma}\end{array}$ & Not identified & upper lower Miocene & $18.2 \mathrm{Ma}$ \\
\hline $\begin{array}{l}\mathrm{m} 5.4 \text { Sand } \\
\text { Above } \\
\text { Below }\end{array}$ & $\overline{-}$ & $\begin{array}{l}0.708619,18.4 \mathrm{Ma} \\
0.708467,20.6 \mathrm{Ma}\end{array}$ & Not identified & upper lower Miocene & $18.4-20.6 \mathrm{Ma}$ \\
\hline $\begin{array}{l}\text { m5.6 True blue** } \\
\text { Above } \\
\text { Below }\end{array}$ & $\begin{array}{l}\text { In Zone NN2 } \\
0.708330,22.0 \mathrm{Ma}\end{array}$ & $\begin{array}{l}\text { Seismically merged with } \mathrm{m} 6 \\
0.708360,22.2 \mathrm{Ma} \text { ? } \\
0.708261,24.0 \mathrm{Ma} \text { ? }\end{array}$ & Not identified & lower Miocene & $\sim 22 \mathrm{Ma}$ \\
\hline $\begin{array}{l}\text { m6 Pink-3** } \\
\text { Above } \\
\text { Below }\end{array}$ & $\begin{array}{l}0.708291,23.2 \mathrm{Ma} \\
0.708171,26.6 \mathrm{Ma}\end{array}$ & $\begin{array}{l}0.708261,24.0 \mathrm{Ma} \\
0.708116,28.2 \mathrm{Ma}\end{array}$ & $\begin{array}{l}0.708296,23.0 \mathrm{Ma} \\
0.708260,24.0 \mathrm{Ma}\end{array}$ & $\begin{array}{l}\text { Oligocene/Miocene boundary } \\
\text { Based on position in } \mathrm{C} 6 \mathrm{C}\end{array}$ & $23.8 \pm 0.2 \mathrm{Ma}$ \\
\hline $\begin{array}{l}\text { ol Green-2** } \\
\text { Above } \\
\text { Below }\end{array}$ & $\begin{array}{l}0.708024,30.8 \mathrm{Ma} \\
\text { NP19-20 }\end{array}$ & $\begin{array}{l}0.708067,29.6 \mathrm{Ma} \\
\text { NP19-20 }\end{array}$ & $\begin{array}{l}0.708117,28.2 \mathrm{Ma} \\
\text { NP19-20 }\end{array}$ & middle Oligocene/upper Eocene & $\begin{array}{l}30.2-36.7 \mathrm{Ma} \\
(-32 \mathrm{Ma} \text { above at Site } 903 \text { based } \\
\text { on extrapolation; } 35.8-36.7 \mathrm{Ma} \\
\text { based on hiatus at Site } 612)\end{array}$ \\
\hline
\end{tabular}

Notes: * = possibly equivalent to the shelf reflectors of this color (Greenlee et al., 1992). ** = possibly equivalent to the shelf reflectors of this color (G.S. Mountain et al., unpubl. data).

gocene (Figs. 8-10). Previously, this "siliciclastic switch" could be dated only as occurring between the late Eocene and middle Oligocene ( $30 \mathrm{Ma})$ at the COST B-3 well (Poag, 1980). Leg 150 drilling obtained a similar age for the timing of this switch, because at Site 903 , it occurred between $\sim 37 \mathrm{Ma}$ (uppermost Eocene) and $\sim 32 \mathrm{Ma}$ (Zone NP23) (Fig. 4). At Site 612 (Figs. 1B, 10; Table 2), $\sim 1 \mathrm{~m}$ of lowermost Oligocene carbonates disconformably overlie upper Eocene carbonates (Poag, Watts, et al., 1987); the hiatus associated with this disconformity was estimated as 37.0 to 35.8 Ma using biostratigraphy and isotopic ( $\mathrm{Sr}$ and oxygen) stratigraphy (Miller et al., 1991a). These previous data establish that the "siliciclastic switch" occurred between $\sim 35.8$ and $\sim 32 \mathrm{Ma}$. Integrating results from two Alvin cores (1619 and $1615.6 \mathrm{~m}$; Table 2) obtained in Lindenkohl Canyon with the borehole results date this switch (Figs. 8,9) between 35.8 (the age of the carbonates at Site 612) and $\sim 34.0 \mathrm{Ma}$ (the minimum age of the upper Alvin core). This change correlates with a global $\delta^{18} \mathrm{O}$ increase (Zone Oil of Miller et al., 1991c; see "Discussion").

The ASP-14 borehole on the slope recorded deposition from $\sim 18$ to $17 \mathrm{Ma}, \sim 15$ to $12 \mathrm{Ma}$, and $\sim 10$ to $9 \mathrm{Ma}$ (using biostratigraphy of Melillo, 1985, and Sr-isotopic data provided in Table 2). At ASP-15 on the slope, there is a sliver of lower Miocene ( 20-19 Ma; C. dissimilis Zone; Melillo, 1985; 19.5 Ma Sr-isotopic age estimate; Table 2 ). This is separated by an unconformity from a thin upper middle Miocene section ( 12 Ma; G. fohsi lobata/robusta; Melillo, 1985; 11.7 Ma Sr-isotopic age estimate), which is, in turn, separated by an unconformity from upper Miocene ( $\sim 9 \mathrm{Ma}$; G. conomiozea; Melillo, 1985) strata (Table 2).

\section{DISCUSSION}

\section{Age Estimate of Oligocene-Middle Miocene Reflectors}

We synthesize our Sr-isotopic ages for Reflectors ol to $\mathrm{m} 1$ with available biostratigraphic and magnetostratigraphic data to obtain age estimates (Table 3). Reflector o1 (Green-2) is associated with a long hiatus at Sites 902, 903, 904, and 906; the shortest hiatus occurred at Site 903 ( 37-32 Ma). Comparison with the Site 612 and Alvin records (Fig. 10) suggests that this long hiatus in the Leg 150 boreholes represents the concatenation of at least two events, earliest Oligocene (36.7-35.8 Ma) and middle Oligocene ( 34-32 Ma). We suggest that this reflector may be equivalent to the earliest Oligocene hiatus dated at Site 612 as 35.8-36.7 Ma (Miller et al., 1991a) (Fig. 10).

Reflector m6 (Pink-3) spans the Oligocene/Miocene boundary at Sites 902, 903, 904, and 906, with hiatuses at Sites 902 (26.6-23.2 Ma), 903 (28.2-24.0 Ma), and 906 (merged with Reflectors m3-m5; hiatus $27.0-13.5 \mathrm{Ma}$ ). The best age estimate for this reflector is provided at Site 904, where it appears to be conformable. At Site 904, it correlates with Chronozone $\mathrm{C} 6 \mathrm{Cn}$; it probably correlates with the reversed interval between Chrons $\mathrm{C} 6 \mathrm{Cn} 2$ and $\mathrm{C} 6 \mathrm{Cn} 3, \sim 23.8 \mathrm{Ma}$, although only two of three normal subchrons in $\mathrm{C} 6 \mathrm{Cn}$ appear to be represented (error $\sim 23.6-24.0 \mathrm{Ma}$; Table 3; Fig. 10).

The ages of the early Miocene reflectors are reasonably well constrained. Reflector 5.6 (True blue) is dated at Site 902 as $22 \mathrm{Ma}$. At Site 903, Reflector 5.6 cannot be distinguished on available seismic profiles from Reflector $\mathrm{m} 6$, although it may be associated with a possible hiatus from 24 to $22 \mathrm{Ma}$. Reflector m5.4 (Sand) is dated at Site 903 as 20.6-18.4 Ma. Reflector 5.2 (Ochre) is constrained at Site 903 as $\sim 18.2-18.3 \mathrm{Ma}$. Reflector $\mathrm{m} 5$ (Green) is associated with hiatuses of 18.1-16.9 Ma at Site 904 and 18.2-16.3 Ma at Site 903 (Table 3).

At Site 903, Reflectors m4 (Pink-2) and m3 (Blue) are dated as $\sim 14.8$ and $13.6 \mathrm{Ma}$, respectively, based on interpolation of sedimentation rates between magnetostratigraphic, $\mathrm{Sr}$-isotopic, and biostratigraphic datum levels (Fig. 4; Table 3). This appears to contradict the Sr-isotopic ages of $12.5 \mathrm{Ma}$ for this reflector at Site 903 (Table 3), but this $1 \mathrm{~m}$.y. difference is within the age uncertainties of the Sr-isotopic estimates. Merged Reflectors $\mathrm{m} 3 / \mathrm{m} 4$ (Blue) appear to correlate with the 16.0-13.0 Ma hiatus at Site 904, and merged Reflectors m3-m6 are associated with a hiatus from $\sim 27.0-13.5 \mathrm{Ma}$ at Site 906 . The 


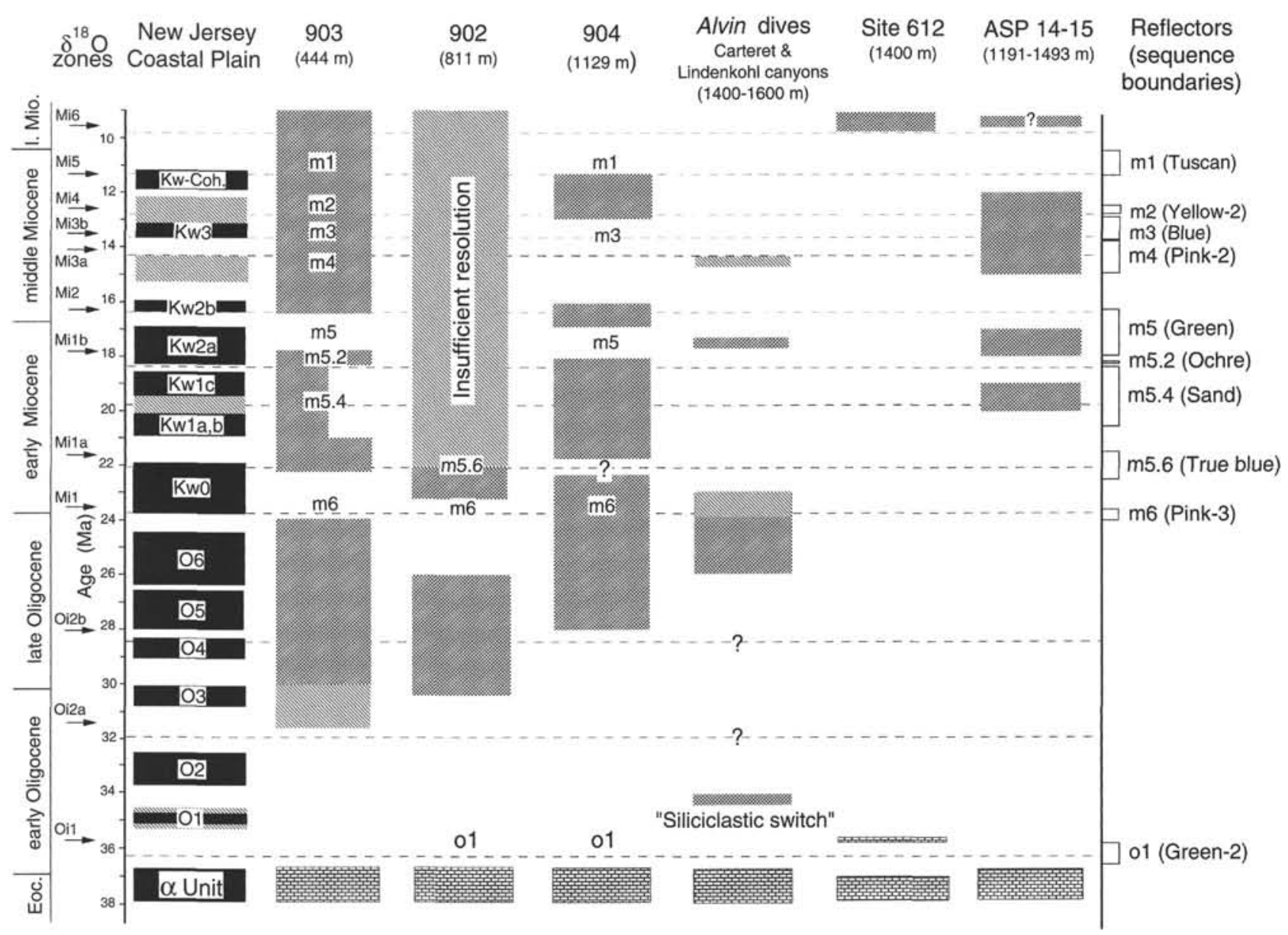

Figure 10. Comparison of hiatuses on the New Jersey continental slope with those in the New Jersey coastal plain. Slope sites are arranged left to right from shallow to deeper water depths. Shaded intervals indicate time represented by section at each location, cross-hatched intervals indicate uncertain age control. Coastal plain Miocene section after Miller and Sugarman (1995); Oligocene section after Pekar and Miller (1994). O1-O6 are onshore Oligocene sequences. $\mathrm{Kw} 0-\mathrm{Kw} 3$ and $\mathrm{Kw}$-Coh. are onshore Miocene Kirkwood and Cohansey sequences. The oxygen isotopic zones are defined by maximum $\delta^{18} \mathrm{O}$ values $(\mathrm{Miller}$ et al., 1991c; Wright and Miller, 1992); dashed lines indicate the inflection in the timing of the $\delta^{18} \mathrm{O}$ increases associated with the zones. Note that Zone Mi3 is divided into Mi3a and Mi3b based on the $\delta^{18} \mathrm{O}$ record at Site 747 (Wright and Miller, 1992). o1, m6, m5, m4, m3, m2, and $\mathrm{m} 1$ are reflectors correlated to each site (Mountain, Miller, Blum, et al., 1994), and the errors for the ages of the reflectors (Table 3) are shown in the right-hand column.

ages of these reflectors still have large uncertainties (15.0-13.8 Ma for $\mathrm{m} 4$ and 12.8-13.6 Ma for m3; Table 3; Fig. 10).

Reflector m2 (Yellow-2) is well dated as 12.6-12.5 Ma at Site 904 and 12.6 Ma at Site 903 based on interpolation of sedimentation rates between magnetostratigraphic, $\mathrm{Sr}$-isotopic, and biostratigraphic datum levels. Reflector $\mathrm{ml}$ (Tuscan) is associated with a hiatus from $\sim 11.3 \mathrm{Ma}$ to 8.9-8.3 Ma at Site 904. Shipboard studies suggested that Reflector $\mathrm{m} 1$ was tentatively associated with Chronozone C5r2 $(10.54-11.03 \mathrm{Ma})$ at Site 903 and with a possible hiatus that removed Chron C5n $(9.7 \pm 0.7 \mathrm{Ma})$ at Site 902 . This discrepancy has not been resolved, and the precise age of Reflector $\mathrm{ml}$ is still not well constrained, although it appears to be younger than $11.3 \mathrm{Ma}$ based on Site 904, and older than $\sim 10.5-10.6$ Ma based on its placement below Chronozone C5n (>10.42 Ma) at Site 903 (Van Fossen and Urbat, this volume).

\section{Climatic and Sediment Supply Effects on Sedimentation: The "Siliciclastic Switch"}

A regional change in depositional environment, the "siliciclastic switch," occurred in the earliest Oligocene on the New Jersey slope. In Lindenkohl Canyon, Eocene carbonates are separated from Oli- gocene terrigenous muds and sands by an unconformity that represents an earliest Oligocene ( $37-34 \mathrm{Ma}$ ) hiatus (Figs. 8-10). This establishes the timing of the "siliciclastic switch" as earliest Oligocene. At Site 612, a similar unconformity separates upper Eocene carbonates from a thin $(\sim 1 \mathrm{~m})$ lowermost Oligocene carbonate section (Poag, Watts, et al., 1987; Miller et al., 1991a). The Oligocene carbonates overlying the unconformity at Site 612 appear to be older (best estimate is $35.8 \mathrm{Ma}$, error range $36.6-34.8 \mathrm{Ma}$; Miller et al., 1991a) than the Oligocene terrigenous sediments in Lindenkohl Canyon (best estimate is $34 \mathrm{Ma}$, although they could be as old as $35 \mathrm{Ma}$ ) at the adjacent outcrop, thus dating the change in depositional regime as $\sim 34.5 \mathrm{Ma}$ (Fig. 10). This immediately postdates the global earliest Oligocene $\delta^{18} \mathrm{O}$ increase that culminated in maximum values at 35.8 $\mathrm{Ma}$ (= base of oxygen isotope Zone Oil of Miller et al., 1991c).

We suggest that regional climate dramatically changed on the East Coast of the United States in the earliest Oligocene and that this caused the "siliciclastic switch"; the regional cooling was a response to global climate changes associated with a major phase of Antarctic ice growth (e.g., Miller et al., 1991c). Pollen studies in New Jersey at the onshore ACGS\#4 borehole show that a major cooling occurred in the earliest Oligocene ( 35-34 Ma; Owens et al., 1988). This regional cooling correlates with the siliciclastic switch on the slope with a 
few 100 k.y. Cooler surface water temperatures may have inhibited carbonate production, particularly on the wide ramp-type shelf. This decrease in supply of carbonates resulted in a decrease in sedimentation rate from moderate rates (e.g., $35 \mathrm{~m} / \mathrm{m}$.y. at Site 612) of Eocene slope carbonate accumulation to slow rates (e.g., $16 \mathrm{~m} / \mathrm{m}$.y. at Site 902) of Oligocene slope clay accumulation.

Early work established that by the middle Miocene, thick clinoforms prograded beneath what is now the New Jersey continental shelf (e.g., Schlee, 1981). The section above Reflector Blue (Greenlee et al., 1992; = m3 of Mountain, Miller, Blum, et al., 1994), dated as $\sim 13.6 \mathrm{Ma}$ (see below), shows the most dramatic increase in progradation and channel cutting (Mountain et al., this volume). However, progradation began prior to this. Greenlee et al. (1992) used industry wells to date well-developed prograding lower Miocene clinoforms beneath the modern inner shelf. Greenlee et al. (1988) suggested that shelf clinoforms began in the middle Oligocene by correlating to the cycle chart of Haq et al. (1987). Borehole control is limited on the inner shelf to confirm this, although the upper Oligocene section recovered at the inner shelf AMCOR 6011 borehole (Hathaway et al., 1976) is consistent with this middle Oligocene initiation of progradation.

Middle to late Oligocene progradation noted beneath the presentday shelf is also expressed in New Jersey onshore facies. At Atlantic City (Miller et al., 1994a, 1994b) and other onshore boreholes (Olsson et al., 1980; Owens et al., 1988), the upper Oligocene contains a significantly greater amount of quartz sand than below, reflecting an increase in coarse terrigenous input. At Cape May, New Jersey, a fundamental change in depositional regime occurred near the beginning of the Miocene, with a change from glauconite-dominated shelfal deposition to deltaic deposition (Cape May site report [Miller et al., 150X (Suppl.), this volume]; Miller and Sugarman, 1995).

The development of a high-sedimentation rate, prograding margin occurred over a 20-m.y. interval: (1) the middle Oligocene saw the first seismically resolvable prograding clinoforms and an increase in coarse clastics on shore; (2) by the earliest Miocene, deltaic sedimentation reigned onshore and thick (hundreds of meters) clinoforms developed beneath the modern inner shelf; (3) by the middle Miocene, the locus of sedimentation switched to beneath the modern middle shelf, very thick clinoforms were deposited, channels incised the shelf, the first major slope canyons were cut (Mountain et al., this volume), and slope sedimentation rates increased dramatically (to $>30 \mathrm{~m} / \mathrm{m} . \mathrm{y}$.); and (4) by the late Neogene, the locus of sedimentation switched to beneath the modern outer shelf, canyon formation became widespread on the slope, and slope sedimentation rates increased to $\sim 300 \mathrm{~m} / \mathrm{m}$.y.

While the switch from an Eocene carbonate factory to a starved early Oligocene siliciclastic margin can be ascribed to climate, the middle Oligocene to middle Miocene development of a high-sedimentation rate, prograding regime cannot be ascribed to climate effects alone because global climate both warmed and cooled during this interval (e.g., Miller et al., 1987a). Poag and Sevon (1989) and Pazzaglia (1993) ascribed Oligocene to Miocene evolution to changes in sediment supply linked to hinterland tectonics. We suggest one other mechanism: sea-level change. Kominz (1984) showed that over the long term $\left(10^{6}-10^{7} \mathrm{yr}\right.$ scale; the "first order" fall of Vail et al., 1977), sea-level fell $>50 \mathrm{~m}$ during the middle to late Eocene, $\sim 30 \mathrm{~m}$ in the Oligocene to middle Miocene, and only $15 \mathrm{~m}$ since. These changes are exemplified in the coastal plain by a general shallowing from the early Eocene ( $150 \mathrm{~m}$ paleodepth), to the late Eocene-Oligocene (50 m paleodepth; Christensen et al., 1995), to the middle Miocene ( $\sim 30 \mathrm{~m}$ paleodepth). We suggest that the relative fall in sea level from the early Eocene to the middle Miocene resulted in a constriction of the broad ramp margin that reduced the area available for pelagic production and caused increased input of coarse clastics resulting from base level lowering. Further studies of provenance (e.g., Pazzaglia, 1993), sediment-mass distributions (e.g., Poag and Sevon,
1989), and Appalachian peneplanation are needed to evaluate the roles of hinterland tectonics vs. sea-level change.

The siliciclastic switch is more than a regional phenomenon restricted to the New Jersey Margin. The change from an Eocene carbonate ramp to a starved, siliciclastic Oligocene margin to prograding Neogene clinoforms occurred on margins throughout the world (e.g., Bartek et al., 1991; Steckler et al., 1995), testifying to the importance of climatic controls on sedimentation. On most margins, the timing of the switch is poorly constrained as sometime in the Oligocene (Steckler et al., 1995). On the New Jersey slope, Alvin sampling and ODP drilling establish the timing as earliest Oligocene $(\sim 34.5 \mathrm{Ma})$; we relate the switch to global and regional cooling.

\section{Cryptic Early Oligocene}

Lower Oligocene sediments are poorly represented on the continental slope because of coalesced unconformities. The only definite lower Oligocene sediments sampled were a few meters of lowermost Oligocene (Zone P18, Dive 2174, and Site 612; Table 2), lower Oligocene (Dive 2171, Zone P19; Table 2), and uppermost lower Oligocene (Site 902, 30.4 Ma). Some or all of Zone NP23 at Site 903 may be lower Oligocene (Fig. 4), although NP23 is thin at this site. Lower Oligocene sediments are also rare onshore (e.g., Olsson et al., 1980) and on the rise (e.g., Mountain and Tucholke, 1985).

The paucity of lower Oligocene sediments on the entire margin has yet to be explained. One possibility is that it is a sampling artifact. Onshore drilling has shown that the absence of lower Oligocene is partly the result of insufficient sampling. Drilling at Atlantic City and Cape May recovered lower Oligocene strata (Miller et al., 1994a; Cape May site report [Miller et al., 150X (Suppl.), this volume]). Absence of lower Oligocene sediments in rise boreholes may be explained by strong bottom current erosion associated with a pulse of Northern Component Water (Mountain and Tucholke, 1985), although the rise is still poorly sampled. In contrast, a sufficient number of holes have been drilled on the slope to document that the scarcity of lower Oligocene slope sediments cannot be ascribed entirely to sampling bias.

McGinnis et al. (1993) attributed the paucity of Oligocene sediments to backtilting of the slope. This tectonic mechanism is based on a flexural response of the slope to removal of rise sediments by bottom currents. This is a reasonable mechanism and can explain the apparent dip inversions observed on Ew9009 seismic profiles. We offer another possible mechanism related to changes in sediment supply. As noted above, the margin evolved from a pelagic dominated, carbonate margin with a gentle slope (i.e., a ramp) in the Eocene to a starved early Oligocene shelf and slope to a prograding siliciclastic margin by the late Oligocene. Starvation of the shelf and slope combined with the effects of swift bottom currents on the lower slope and upper rise conspired to rob us of the early Oligocene record on this margin.

\section{Correlation to Glacioeustatic Proxy and Onshore Drilling}

Foraminiferal oxygen isotopes reflect changes in temperature, ice volume, and local effects. Ice volume changes are recorded as synchronous changes in benthic and low-latitude (nonupwelling) planktonic foraminiferal $\delta^{18} \mathrm{O}$ records (see summary and discussion in Miller et al., 1991c, and Miller and Mountain, 1994). Previous studies identified 12 global Oligocene to early late Miocene $\delta^{18} \mathrm{O}$ increases (all $>0.5 \%$ ) recorded by benthic foraminifers (with the maximum values used to define oxygen isotope Zones Oil-Oi2; Mi1-Mi7; Fig. 10) (Miller et al., 1991c; Wright and Miller, 1992). These $\delta^{18} \mathrm{O}$ increases are well dated in sections with good magnetostratigraphy (e.g., age resolution much better than 0.5 m.y.). Six of these $\delta^{18} \mathrm{O}$ increases also occur in tropical or subtropical planktonic foraminifers (the other six lack suitable low-latitude records). Such covariance be- 
tween the benthic and planktonic $\delta^{18} \mathrm{O}$ records is attributed to ice growth, and these Oligocene-early late Miocene $\delta^{18} \mathrm{O}$ increases (indicated as dashed lines on Fig. 10) are interpreted as glacioeustatic lowerings (Miller et al., 1991c; Wright and Miller, 1992). This is supported by the link of Oligocene benthic foraminiferal $\delta^{18} \mathrm{O}$ increases (=Zones Oi1, Oi2, Mi1) with intervals of glacial sedimentation near Antarctica and a tentative correlation of these 12 isotopic increases with 12 sequence boundaries (= inferred eustatic lowerings) of $\mathrm{Haq}$ et al. (1987) (see Miller et al., 1991c; Wright and Miller, 1992, for discussion).

We compare the record of deposition on the slope with that on the New Jersey coastal plain and with a proxy for glacioeustasy afforded by the global $\delta^{18} \mathrm{O}$ record (Fig. 10) (Miller et al., 1991c; Wright and Miller, 1992). Hiatuses on shore agree well with the timing of the $\delta^{18} \mathrm{O}$ increases (indicated by thin dashed lines, Fig. 10); this is not surprising if eustasy is a dominant control on these shallow-water (neritic-nearshore) deposits (Miller and Sugarman, 1995).

There is excellent correlation between the timing of the major slope reflectors dated at Leg 150 sites and glacioeustatic lowerings. Reflectors ol, m6, m5.6, m5.4, m5, m4, m3, m2, and $\mathrm{m} 1$ correlate with the Oil, Mil, Mila, Milb, Mi2, Mi3a, Mi3b, Mi4, and Mi5 $\delta^{18} \mathrm{O}$ increases, respectively (Fig. 10). This confirms a link between sequence boundaries traced from the shelf and glacioeustatic changes in sea level. Of the reflectors, only $\mathrm{m} 5.4$ (a poorly resolved reflector) does not appear to have a corresponding $\delta^{18} \mathrm{O}$ increase. Of the $\delta^{18} \mathrm{O}$ increases, only Oligocene Zones Oi2a and Oi2b fail to have equivalent reflectors due to poor resolution of Oligocene seismic sequences. Note that the reflectors on the slope are not always associated with detectable hiatuses (Fig. 10), in part because these sites represent relatively continuous records based on seismic profiles. Correlation between reflectors and $\delta^{18} \mathrm{O}$ increases attains one of the major goals of Leg 150.

The correlations made here between the reflectors and $\delta^{18} \mathrm{O}$ are remarkable considering the problems in dating the slope sequences. As noted above, maximum $\mathrm{Sr}$-isotopic resolution is $\pm 0.4 \mathrm{~m} . \mathrm{y}$. and is much worse in the middle Miocene. Given this resolution, one could argue that the correlations shown on Figure 10 are fortuitous. Making a similar argument, Miall (1991) claimed that stratigraphic resolution was insufficient to document precise correlation between New Jersey sequences and the Haq et al. (1987) global synthesis or a causal link between sequences and sea level. We argue that the correlations of sequence boundaries and $\delta^{18} \mathrm{O}$ increases (Fig. 10) are valid and that glacioeustatic lowerings correlate with hiatuses onshore and with reflectors (sequence boundaries) on the shelf and slope. Although stratigraphic resolution is still coarse in some intervals (e.g., Reflectors $\mathrm{m} 1, \mathrm{~m} 5$, and $\mathrm{m} 5.4$ have at least a $0.8,1.7$, and 2.2 m.y. age uncertainties, respectively; Table 3 ), other reflectors are well dated by integration of $\mathrm{Sr}$-isotopic, magnetostratigraphic, and biostratigraphic data. For example, there is little doubt that Reflector m6 (dated at $23.8 \pm 0.2 \mathrm{Ma}$ at Site 904 ; associated with hiatuses from 26.6 to 23.2 and 28.2 to $23.2 \mathrm{Ma}$ at Sites 902 and 903 , respectively) is associated with the Oligocene/Miocene boundary and that it correlates very well (Fig. 10) with the Mil oxygen isotopic increase (inflection at 23.7 Ma; Miller et al., 1991c). In contrast to Miall's view, we believe that it is not necessary to demonstrate that every event correlates with better than 0.5 m.y. resolution. By anchoring key stratigraphic levels (e.g., Reflector m6) to a precise chronology and by having a similar number of events in both the margin and $\delta^{18} \mathrm{O}$ records, we believe that reliable correlations can be established and causality can be inferred.

The relationship between $\delta^{18} \mathrm{O}$ increases and slope hiatuses is less clear (Fig. 10). This is not surprising considering that the link between slope failure and sea level is indirect. As summarized by Miller and Mountain (1994), slope failure may be attributed to various mechanisms including seismicity, burrowing by benthic fauna, undercutting by bottom currents, groundwater sapping, changes in sediment supply from the shelf, and diagenesis leading to jointing and collapse (see references in Miller and Mountain, 1994). Of these, only changes in terrestrial sediment supply and sapping can be linked directly to changes in sea level. Nevertheless, previous studies have found that unconformities on continental slopes appear to correlate with other proxies for sea-level lowering (e.g., Miller et al., 1987a; Snyder and Waters, 1985; Poag and Low, 1987; Miller and Hart, 1987; Aubry, 1991) and have implied that continental slopes provide monitors, albeit indirect, of global sea-level lowering. Several hiatuses on the slope correspond well with the inferred glacioeustatic record (Fig. 10), supporting this implication:

1. An earliest Oligocene hiatus dated at Site 612 and Lindenkohl Canyon correlates very well with a hiatus in the onshore coastal plain and with the Oil global $\delta^{18} \mathrm{O}$ increase (Miller et al., 1991c). This $\delta^{18} \mathrm{O}$ increase represents a glacioeustatic lowering of at least $30 \mathrm{~m}$ (Miller et al., 1991c) and clearly establishes a link between eustatic change and slope erosion.

2. A hiatus spanning the Oligocene/Miocene boundary at Sites 902 and 903 is associated with Reflector m6 and correlates with the Mil $\delta^{18} \mathrm{O}$ increase that also spans the Oligocene/Miocene boundary. It can be traced to a correlative conformity at Site 904 where the reflector is dated as $23.9 \mathrm{Ma}$, in excellent agreement with the timing of the maximum rate of $\delta^{18} \mathrm{O}$ increase.

3. A hiatus spanning the early/middle Miocene boundary at Sites 903 and 904 and ASP-14 is associated with Reflector m5 and correlates with the $\mathrm{Mi} 2 \delta^{18} \mathrm{O}$ increase.

Initial efforts to evaluate sea-level effects on Oligocene-Miocene slope deposition were frustrated by long hiatuses on the slope (e.g., most of the Oligocene to middle Miocene at Site 612; the middle middle Miocene at ASP-14-15) (e.g., Leg 95, Poag, Watts, et al., 1987; Miller et al., 1987b). The cores obtained on Leg 150 fulfilled the promise begun with the New Jersey Transect in 1983 (Poag, Watts, et al., 1987; van Hinte, Wise, et al., 1987) by recovering sufficiently continuous records to evaluate the timing of sequences. The task of evaluating the ages of the hiatuses and sequence boundaries has begun with our Sr-isotopic studies and preliminary integration with planktonic foraminifer studies (Snyder et al., this volume), nannofossil shipboard studies, and magnetostratigraphic studies (Van Fossen and Urbat, this volume). This task will be completed when these studies are integrated with ongoing studies of nannofossils (Aubry, this volume), radiolarians (Nigrini, this volume), diatoms (Burckle, this volume), and dinocysts (de Verteuil, this volume).

\section{CONCLUSIONS}

$\mathrm{Sr}$ isotopes provide an excellent means of correlating Oligocene to Miocene strata on the New Jersey slope to the time scale, circumventing problems encountered with biostratigraphic correlations resulting from rare calcareous zonal markers. By integrating Sr-isotopic stratigraphy with planktonic foraminifer biostratigraphy (Snyder et al., this volume), shipboard nannofossil biostratigraphy, and magnetostratigraphy (Van Fossen and Urbat, this volume), we are able to provide a preliminary chronology of Oligocene to middle Miocene deposition at ODP sites and slope outcrops as outlined here.

Site 904. The upper Oligocene to lower lower Miocene section $(\sim 28$ to $18 \mathrm{Ma})$ is continuous within the resolution of Sr-isotopic stratigraphy. A possible earliest Miocene hiatus inferred from foraminiferal studies may reflect a premature highest occurrence, similar to delayed lowest occurrences noted in the middle Miocene. Sr-isotopic age estimates indicate hiatuses between 18.1 and $16.9 \mathrm{Ma}$ and between 16.0 and 13.0 Ma and continuous upper middle Miocene sections (13.2-11.3 Ma).

Site 903. We make a conservative interpretation of continuous Oligocene sedimentation between $\sim 32$ and $27.8 \mathrm{Ma}$. Sr-isotopic 
stratigraphy indicates at least one hiatus (27.8-22.2 Ma) spanning the Oligocene/Miocene boundary, another possible hiatus from 21 to 18.4 Ma, a major hiatus from 18.2 to $16.4 \mathrm{Ma}$, and no discernible gaps from $\sim 16.4-12.5 \mathrm{Ma}$.

Site 902. After a major early Oligocene hiatus, deposition resumed at $30.4 \mathrm{Ma}$ in the latest early Oligocene and continued until 27-26 Ma. Another hiatus occurred until $22 \mathrm{Ma}$. The rest of the Miocene section lacked carbonate fossils for $\mathrm{Sr}$-isotopic study.

Site 906. The age of the Oligocene section is virtually identical to that at nearby ( $3.3 \mathrm{~km}$ away) Site 902 . A major hiatus separates the upper Oligocene from the middle Miocene.

Slope Outcrops. Because of a long early Oligocene hiatus at the Leg 150 sites, the upper Eocene to lower Oligocene section at Lindenkohl Canyon provides the only precise date (34.5 Ma) on the timing of the "siliciclastic switch" from carbonate to siliciclastic sedimentation. Carteret Canyon outcrops recorded hiatuses from 23.8 to $\sim 18 \mathrm{Ma}$ (early Miocene), $\sim 17$ to $15 \mathrm{Ma}$ (early to middle Miocene), and $\sim 14.5-5 \mathrm{Ma}$ (middle Miocene to early Pliocene).

The chronology presented here is preliminary because it does not integrate ongoing nannofossil (Aubry, this volume), radiolarian (Nigrini, this volume), diatom (Burckle, this volume), and dinocyst (de Verteuil, this volume) studies. Nevertheless, our comparisons of the timing of sequences on this margin with the oxygen isotopic proxy of glacioeustasy are encouraging. Of the 10 Oligocene to middle Miocene reflectors identified by Mountain, Miller, Blum, et al. (1994), nine correlate with the $\delta^{18} \mathrm{O}$ events and with sequence boundaries on shore (Miller et al., 1994a, 1994b). Because these reflectors can be traced to sequences on the shelf, this suggests that shelf and slope sequences are causally related to eustatic lowerings.

\section{ACKNOWLEDGMENTS}

We thank our Leg 150 colleagues for making this study possible. In particular, collaboration with M.-P. Aubry (nannofossils), L. Burckle (diatoms), L. de Verteuil (dinocysts), M. Katz (benthic foraminifers), G. Mountain (seismic stratigraphy), S. Snyder (planktonic foraminifers), and M. Van Fossen (magnetostratigraphy) made Figures $2-5$ possible. We thank the captain and crew of the Atlantis II, the pilots of the DSV Alvin, and the scientific party of AII 120 and 124 for collecting the Alvin cores. In particular, D. Twichell (Dive 2169), B. Christensen (Dive 2174), and J. Wright (Dive 2174) were observers who recovered the Oligocene-Miocene outcrops, and their astute field work is appreciated. A. Palmer-Julson provided radiolarian biostratigraphy of the Alvin samples, J. Wright and A. Brower collaborated in shipboard interpretation of the planktonic foraminiferal biostratigraphy of the Alvin samples, and C. Padover processed Alvin samples for Sr-isotopic analyses. We thank W. Ryan and D. Twichell for the SeaBeam data and B. Christensen for preparing a draft copy of the SeaBeam bathymetry. We thank E. Barrera, J. Browning, D. Hodell, M. Katz, and G. Mountain for reviews. Samples were provided by ODP. This study was supported by NSF grants OCE88-17563 (Ryan, Miller), OCE89-11810 (Mountain, Miller), and OCE92-03282 (Mountain, Miller) and JOI/USSAC. This is Lamont-Doherty Earth Observatory contribution number 5497.

\section{REFERENCES}

Aubry, M.-P., 1991. Sequence stratigraphy: eustasy or tectonic imprint? J. Geophys. Res., 96:6641-6679.

Bartek, L.R., Vail, P.R., Anderson, J.B., Emmet, P.A., and Wu, S., 1991. Effect of Cenozoic ice sheet fluctuations in Antarctica on the stratigraphic signature of the Neogene. J. Geophys. Res., 96:6753-6778.

Berggren, W.A., Kent, D.V., Flynn, J.J., and Van Couvering, J.A., 1985. Cenozoic geochronology. Geol. Soc. Am. Bull., 96:1407-1418.

Berggren, W.A., Kent, D.V., Swisher, C.C., III, and Aubry, M.-P., in press. A revised Cenozoic geochronology and chronostratigraphy. In Berggren,
W.A., Kent, D.V., and Hardenbol, J. (Eds.), Geochronology, Time Scales, and Global Stratigraphic Correlations: A Unified Temporal Framework for an Historical Geology. Spec. Publ.-Soc. Econ. Paleontol. Mineral., 54.

Cande, S.C., and Kent, D.V., 1992. A new geomagnetic polarity time scale for the Late Cretaceous and Cenozoic. J. Geophys. Res., 97:1391713951.

, 1995. Revised calibration of the geomagnetic polarity timescale for the Late Cretaceous and Cenozoic. J. Geophys. Res., 100:6093-6095.

Christensen, B.A., Miller, K.G., and Olsson, R.K., 1995. Eocene-Oligocene benthic foraminiferal biofacies and depositional sequence at the ACGS\#4 borehole, New Jersey coastal plain. Palaios, 10:103-132.

Farre, J.A., and Ryan, W.B.F., 1987. Surficial geology of the continental margin offshore New Jersey in the vicinity of Deep Sea Drilling Project Sites 612 and 613. In Poag, C.W., Watts, A.B., et al., Init. Repts. DSDP, 95: Washington (U.S. Govt. Printing Office), 725-759.

Greenlee, S.M., Devlin, W.J., Miller, K.G., Mountain, G.S., and Flemings, P.B., 1992. Integrated sequence stratigraphy of Neogene deposits, New Jersey continental shelf and slope: comparison with the Exxon model. Geol. Soc. Am. Bull., 104:1403-1411.

Greenlee, S.M., and Moore, T.C., 1988. Recognition and interpretation of depositional sequences and calculation of sea level changes from stratigraphic data-offshore New Jersey and Alabama Tertiary. In Wilgus, C.K., Posamentier, H., Ross, C.A., and Kendall, C.G.St.C. (Eds.), SeaLevel Changes: An Integrated Approach. Spec. Publ.-Soc. Econ. Paleontol. Mineral., 42:329-353.

Greenlee, S.M., Schroeder, F.W., and Vail, P.R., 1988. Seismic stratigraphic and geohistory analysis of Tertiary strata from the continental shelf off New Jersey: calculation of eustatic fluctuations from stratigraphic data. In Sheridan, R.E., and Grow, J.A. (Eds.), The Atlantic Continental Margin. Geol. Soc. Am., Geol. of North Am. Ser., 437-444.

Haq, B.U., Hardenbol, J., and Vail, P.R., 1987. Chronology of fluctuating sea levels since the Triassic. Science, 235:1156-1167.

Hathaway, J.C., Schlee, J., Poag, C.W., Valentine, P.C., Weed, E.G.A., Bothner, M.H., Kohout, F.A., Manheim, F.T., Schoen, R., Miller, R.E., and Schultz, D.M., 1976. Preliminary study of the 1976 Atlantic Margin Coring Project of the U.S. Geological Survey. Open-File Rep.-U.S. Geol. Surv., 76-844.

Kominz, M.A., 1984. Oceanic ridge volumes and sea-level change - an error analysis. In Schlee, J.S. (Ed.), Interregional Unconformities and Hydrocarbon Accumulation. AAPG Mem., 36:37-58.

McGinnis, J.P., Driscoll, N.W., Karner, G.D., Brumbaugh, W.D., and Cameron, N., 1993. Flexural response of passive margins to deep-sea erosion and slope retreat: implications for relative sea-level change. Geology, 21:893-896.

Melillo, A.J., 1985. Late Oligocene to Pliocene sea-level cycle events in the Baltimore Canyon Trough and western North Atlantic basin [Ph.D. thesis]. Rutgers Univ., New Brunswick, NJ.

Miall, A.D., 1991. Stratigraphic sequences and their chronostratigraphic correlation. J. Sediment. Petrol., 61:497-505.

Miller, K.G., Berggren, W.A., Zhang, J., and Palmer-Julson, A., 1991a. Biostratigraphy and isotope stratigraphy of upper Eocene microtektites at Site 612: how many impacts? Palaios, 6:17-38.

Miller, K.G., Browning, J.V., Liu, C., Sugarman, P., Kent, D.V., Van Fossen, M., Queen, D., Goss, M., Gwynn, D., Mullikin, L., Feigenson, M.D., Aubry, M.-P., and Burckle, L.D., 1994a. Atlantic City site report. In Miller, K.G., et al., Proc. ODP, Init. Repts., 150X: College Station, TX (Ocean Drilling Program), 35-55.

Miller, K.G., Fairbanks, R.G., and Mountain, G.S., 1987a. Tertiary oxygen isotope synthesis, sea-level history, and continental margin erosion. Paleoceanography, 2:1-19.

Miller, K.G., Feigenson, M.D., Kent, D.V., and Olsson, R.K., 1988. Upper Eocene to Oligocene isotope $\left({ }^{87} \mathrm{Sr} /{ }^{86} \mathrm{Sr}, \delta^{18} \mathrm{O}, \delta^{13} \mathrm{C}\right)$ standard section, Deep Sea Drilling Project Site 522. Paleoceanography, 3:223-233.

Miller, K.G., Feigenson, M.D., Wright, J.D., and Clement, B.M., 1991b. Miocene isotope reference section, Deep Sea Drilling Project Site 608: an evaluation of isotope and biostratigraphic resolution. Paleoceanography, 6:33-52.

Miller, K.G., and Hart, M., 1987. Cenozoic planktonic foraminifera, DSDP Leg 95 (northwest Atlantic) and hiatuses on the New Jersey Slope and Rise. In Poag, C.W., Watts, A.B., et al., Init. Repts. DSDP, 95: Washington (U.S. Govt. Printing Office), 253-265.

Miller, K.G., Melillo, A.J., Mountain, G.S., Farre, J.A., and Poag, C.W., 1987b. Middle to late Miocene canyon cutting on the New Jersey conti- 
nental slope: biostratigraphic and seismic stratigraphic evidence. Geology, 15:509-512.

Miller, K.G., and Mountain, G.S., 1994. Global sea-level change and the New Jersey margin. In Mountain, G.S., Miller, K.G., Blum, P., et al., Proc. ODP, Init. Repts., 150: College Station, TX (Ocean Drilling Program), 11-20.

Miller, K.G., and Sugarman, P.J., 1995. Correlating Miocene sequences in onshore New Jersey boreholes (ODP Leg $150 \mathrm{X}$ ) with global $\delta^{18} \mathrm{O}$ and Maryland outcrops. Geology, 23:747-750.

Miller, K.G., Sugarman, P., Van Fossen, M., Liu, C., Browning, J.V., Queen, D., Aubry, M.-P., Burckle, L.D., Goss, M., and Bukry, D., 1994b. Island Beach site report. In Miller, K.G., et al., Proc. ODP, Init. Repts., 150X: College Station, TX (Ocean Drilling Program), 5-33.

Miller, K.G., Wright, J.D., and Fairbanks, R.G., 1991c. Unlocking the Ice House: Oligocene-Miocene oxygen isotopes, eustasy, and margin erosion. J. Geophys. Res., 96:6829-6848.

Mountain, G.S., Miller, K.G., Blum, P., et al., 1994. Proc. ODP, Init. Repts., 150: College Station, TX (Ocean Drilling Program).

Mountain, G.S., and Tucholke, B.E., 1985. Mesozoic and Cenozoic geology of the U.S. Atlantic continental slope and rise. In Poag, C.W. (Ed.), Geologic Evolution of the United States Atlantic Margin: New York (Van Nostrand Reinhold), 293-341.

Olsson, R.K., Miller, K.G., and Ungrady, T.E., 1980. Late Oligocene transgression of middle Atlantic coastal plain. Geology, 8:549-554.

Oslick, J.S., Miller, K.G., Feigenson, M.D., and Wright, J.D., 1994. Oligocene-Miocene strontium isotopes: stratigraphic revisions and correlations to a glacioeustatic record. Paleoceanography, 9:427-443.

Owens, J.P., Bybell, L.M., Paulachok, G., Ager, T.A., Gonzalez, V.M., and Sugarman, P.J., 1988. Stratigraphy of the Tertiary sediments in a 945foot-deep core hole near Mays Landing in the southeastern New Jersey Coastal Plain. Geol. Surv, Prof. Pap. U.S., 1484.

Pazzaglia, F., 1993. Stratigraphy, petrography, and correlation of late Cenozoic middle Atlantic Coastal Plain deposits: implications for late-stage passive-margin geologic evolution. Geol. Soc. Am. Bull., 105:16171634.

Pekar, S.F., and Miller, K.G., 1994. Correlation of Oligocene sequences between the New Jersey and Alabama coastal plains. Abstr. with Progr., 1994 GSA Ann. Meeting, Seattle, A-91.

Poag, C.W., 1980. Foraminiferal stratigraphy, paleoenvironments, and depositional cycles in the outer Baltimore Canyon Trough. In Scholle, P.A. (Ed.), Geological Studies of the COST No. B-3 Well, United States MidAtlantic Continental Slope Area. Geol. Surv. Circ. (U.S.), 833:44-65.

Poag, C.W., and Low, D., 1987. Unconformable sequence boundaries at Deep Sea Drilling Project Site 612, New Jersey Transect: their character- istics and stratigraphic significance. In Poag, C.W., Watts, A.B., et al., Init. Repts. DSDP, 95: Washington (U.S. Govt. Printing Office), 453500.

Poag, C.W., and Sevon, W.D., 1989. A record of Appalachian denudation in postrift Mesozoic and Cenozoic sedimentary deposits of the U.S. middle Atlantic continental margin. Geomorphology, 2:119-157.

Poag, C.W., Watts, A.B., et al., 1987. Init. Repts. DSDP, 95: Washington (U.S. Govt. Printing Office).

Schlee, J.S., 1981. Seismic stratigraphy of Baltimore Canyon Trough. AAPG Bull., 65:26-53.

Sea-Level Working Group, 1992. JOIDES J., 18:28-36.

Snyder, S.W., and Waters, V.J., 1985. Cenozoic planktonic foraminiferal biostratigraphy of the Goban Spur region, Deep Sea Drilling Project Leg 80. In de Graciansky, P.C., Poag, C.W., et al., Init. Repts. DSDP, 80: Washington (U.S. Govt. Printing Office), 439-472.

Steckler, M.S., Seranne, M., and Lavier, L., 1995. From carbonate ramps to clastic progradation: morphology and stratigraphy of continental margins during Tertiary global change. Eos, 76:S118.

Sugarman, P.J., Miller, K.G., Owens, J.P., and Feigenson, M.D., 1993. Strontium isotope and sequence stratigraphy of the Miocene Kirkwood Formation, Southern New Jersey. Geol. Soc. Am. Bull., 105:423-436.

Vail, P.R., Mitchum, R.M., Jr., Todd, R.G., Widmier, J.M., Thompson, S., III, Sangree, J.B., Bubb, J.N., and Hatlelid, W.G., 1977. Seismic stratigraphy and global changes in sea level. In Payton, C.E. (Ed.), Seismic Stratigraphy-Applications to Hydrocarbon Exploration. AAPG Mem., 26:49-221.

Valentine, P.C., 1980. Calcareous nannofossil biostratigraphy, paleoenvironments, and post-Jurassic continental margin development. In Scholle, P.A. (Ed.), Geological Studies of the COST No. B-3 Well, United States Mid-Atlantic Continental Slope Area. Geol. Surv. Circ. (U.S.), 833:6783.

van Hinte, J.A., Wise, S.W., Jr., et al., 1987. Init. Repts. DSDP, 93: Washington (U.S. Govt. Printing Office).

Wright, J.D., and Miller, K.G., 1992. Miocene stable isotope stratigraphy, Site 747, Kerguelen Plateau. In Wise, S.W., Jr., Schlich, R., et al., Proc. ODP, Sci. Results, 120: College Station, TX (Ocean Drilling Program), $855-866$.

Date of initial receipt: 22 February 1995

Date of acceptance: 29 August 1995

Ms 150SR-011 